\title{
Molecular studies of breast cancer in Iran: A Systematic Review
}

\section{Rezvan Esmaeili}

Institute of Cancer Research Division of Breast Cancer Research

Zahra Eslami-S

Breast Cancer Research Center, ACECR, Tehran

Shiva Drayani

Breast Cancer Research Center, ACECR, Tehran

Tayebeh Oghabi Bakhshayesh

Breast Cancer Research Center, ACECR, Tehran

Aliakbar Zare

Breast Cancer Research Center, ACECR.Tehran

Shahpar Haghighat ( $\sim$ haghighat@acecr.ac.ir)

Breast Cancer research Center, Motamed Cancer Institute, ACECR, Tehran, Iran https://orcid.org/0000-0001-6938-467X

Keivan Majidzadeh-A

Breast Cancer Research Center, ACECR

\section{Research article}

Keywords: Genetics, Mulecular, breast Cancer, systematic review, Iran

Posted Date: April 27th, 2020

DOI: https://doi.org/10.21203/rs.3.rs-22566/v1

License: (c) (1) This work is licensed under a Creative Commons Attribution 4.0 International License. Read Full License 


\section{Abstract}

Background: The present study aimed to review the existing cellular and molecular research systematically carried out in the field of breast cancer in Iran. This study was part of a big project, which evaluated a variety of studies conducted on breast cancer in Iran.

Methods: All molecular articles about breast cancer in Iran which were published from January 2005 to October 21, 2015 were included. English and Persian databases consisted of Web of Science, PubMed, Scopus, Scientific Information Database (SID) and IranMedex. Finally of 3331 abstracts, a total of 379 articles, including 219 English and 160 Persian papers related to molecular studies were included in this study.

Results: After initial evaluations, 240 studies were included. Molecular studies conducted in Iran were divided into four main groups based on their focus. They evaluated breast cancer susceptibility genes, Prognosis and clinicopathologic features of the patients, compounds with therapeutic properties, and diagnosis. Moreover, ethical statements in manuscripts were investigated.

Conclusions: Result of this review showed that most of the researches in Iran categorize to 4 main subjects. The majority of the studies in Iran were conducted sporadically and with small sample sizes. Stronger studies would require the development of more biological banks and execution of multicenter comprehensive projects defined with orientation to main problems of Breast Cancer patients in the country.

\section{Background}

Studies on cancer, especially breast cancer, are extensively ongoing throughout the world. Many Iranian research centers and universities are also working in this field. The present study aimed to review the existing cellular and molecular research carried out in the area of breast cancer in Iran. This study was part of comprehensive research, which evaluated a variety of studies conducted on breast cancer in Iran. The articles reviewed in this study involved molecular studies on genetic susceptibility, diagnosis, Prognosis, survival, therapeutic compounds and clinicopathologic features of breast cancer.

Genetic mutations have a significant role in increasing the risk of breast cancer. In addition to BRCA1/2, low-penetrance genes are also effective in the development of this cancer (1). Therefore, this study sought to collect data on various examined genes from different ethnic groups in Iran. Knowing about the researches which are focusing on genetic mutations in Iran, will make an essential contribution toward decision-making about the design of future studies. On the other hand, since the frequency of younger patients (< 50 years) with breast cancer is higher in Iran compared to western countries (2), the Iranian population might have a particular mutation pattern that affects the risk of breast cancer in younger individuals.

Genotype-phenotype relationship is another critical subject in cancer research. These studies include evaluating the association of genotype and phenotype with the response to treatment and type of clinicopathologic features of patients. Such studies investigated the role of mutations, gene expressions, or epigenetic changes in various subgroups of affected people $(3,4)$.

Herbal medicine and new medications are among the important aspects of drug discovery that many researchers are interested in (5). Vast geographic area and a combination of various animal and plant species in Iran (6) persuade researchers to investigate new anticancer medications. The microbial metabolite, chemical, or synthetic compounds with anticancer properties are another source for drug discovery.

According to the category mentioned above of breast cancer studies and due to the limited budget of research in this country, it is crucial to categorize breast cancer studies. To best of our knowledge, there is not a comprehensive study discussing the mentioned issues. As a result, this systematic review could shed light on the whole picture of studies about the breast cancer molecular susceptibility, treatment, Prognosis, survival and diagnosis in Iran during a decade. It may help organizing the research resources in future.

\section{Methods}

This study was part of a big project evaluating different aspects of breast cancer in Iran. All articles about breast cancer in Iran which were published within a specific period were included and divided into five subgroups. The process of the systematic review was then followed in each subset. Details of the methodology are as follows:

\section{Search Strategy}

All articles published from January 2006 to October 21, 2015, were included. To achieve the most comprehensive search results from electronic medical databases, keywords were extracted from the Medical Subject Headings (MeSH) of PubMed. Online English international electronic databases consisted of Web of Science, PubMed, and Scopus. English search formula was "breast cancer" OR "breast carcinoma" OR "breast tumor" OR "breast neoplasm" AND Iran. Scientific Information Database (SID) and IranMedex. Since using a combined formula was not possible in Persian search, the keywords, including the Persian equivalents of breast tumor, breast cancer, breast carcinoma, and breast neoplasm, and Iran was searched separately and combined with each other. A total of 1986 English and 1345 Persian abstracts were included.

\section{Data screening}

After excluding duplicate articles keywords, three experienced persons in the field of breast cancer screened the initial search results and divided them into five subgroups of epidemiology and risk factors, genetics, prevention, diagnosis and treatment, and rehabilitation. After excluding duplicate and unrelated articles based on title and abstract, 763 English and 572 Persian abstracts were included in those categories. Since some articles were allocated to more than one group, the total of 1646 eligible items entered the process of the systematic review. More details have been published in the previous publication of this project.(7) 
Totally 379 articles included in a molecular subgroup. Full texts of the selected papers were found and, on some occasion, an e-mail was sent to corresponding authors to get the necessary information. Three reviewers used a checklist to appraise the full texts of selected articles critically. The reviewers discussed and resolved any cases of disagreement.

\section{Data extraction}

After reviewing all selected articles, the necessary information was extracted and entered into the study characteristics sheet. Because of the wide variation in the methodology and presented results of the studies chosen, an Excel sheet was used for data extraction. The first part of the datasheet contained general information about the first author, number of authors, title, study design, year of publication, year of the study (midpoint), city and place of the study, study population, sample type, total sample size, and ethnicity, sex, and age of the participants. The second and third parts of data consisted of the method of research and main results, respectively.

Three persons extracted all articles. The manager of the research team organised the three extracted forms in one sheet. The main objective of this study was to clarify the distribution of breast cancer researches in Iran. Therefore, no studies were excluded due to low quality. Duplicate and unrelated articles were excluded from the study. For better quality assessment of the articles, all their limitations were highlighted by entering NA (not assigned) in relevant columns of the results tables.

\section{Data analysis}

In the third step, the extracted data were analyzed. Due to the variety in study fields, the results were categorized according to study designs. The reviewed articles were categorized into five groups, including susceptibility, treatment with the different type of compounds, Prognosis, survival and clinicopathologic features, and diagnosis. However, 17 studies could not be included in any of the mentioned groups. They were, hence, not inserted in the tables but described in the text.

This research has been approved in Breast Cancer Research Center Ethical Committee with ethical code number "IR.ACECR.IBCRC.REC.1394.54"

\section{Results}

A total of 379 articles, including 219 English and 160 Persian papers, were found eligible. After initial evaluations, 139 studies were excluded from the systematic review due to irrelevance $(n=37)$, unavailability of full text $(n=14)$, duplicates $(n=54)$, irrelevance of publication date $(n=12)$, inaccessibility $(n=$ $5)$, and poster $(n=3)$, review studies $(n=12)$, or note articles $(n=2)$. Ultimately, 240 studies were included. (Fig. 1$)$ Duplicates found during this phase were articles published in both Persian and English languages. The reviewed articles were categorized into five groups according to their main themes. The results of the analysis of the papers in each group were as follows:

\section{Susceptibility}

Table 1 summarises the studies in Iran which examined genes related to breast cancer susceptibility. Based on these studies, susceptibility genes were divided into three groups, including high, intermediate, and low penetrance genes. Accordingly, from a total of 62 studies, 21 examined high-penetrance genes, four studied intermediate-penetrance genes, and 38 investigated low-penetrance genes. Moreover, 47 studies were conducted on blood samples, nine on tissue samples, three on blood and tissue samples, and three on cell lines. 
Table 1

Studies focusing on susceptibility genes in breast cancer

\begin{tabular}{|c|c|c|c|c|c|c|c|c|c|c|}
\hline No. & $\begin{array}{l}\text { City of } \\
\text { Study }\end{array}$ & $\begin{array}{l}\text { Type } \\
\text { of } \\
\text { sample }\end{array}$ & $\begin{array}{l}\text { Total } \\
\text { Sample } \\
\text { Size }\end{array}$ & Case & Ctrl & Sex & $\begin{array}{l}\text { Gene /Protein } \\
\text { Name }\end{array}$ & PG & GENE/Protein Alterations & Ref. \\
\hline 1 & Zahedan & Blood & 479 & 262 & 217 & $\mathrm{~F}$ & APOBEC3 & $\mathrm{L}$ & Deletion & $(40)$ \\
\hline 2 & Ahvaz & Blood & 70 & 38 & 32 & $\mathrm{~F}$ & BRCA1 & $\mathrm{H}$ & 185delAG exon2,617delT exon11 & $(41)$ \\
\hline 3 & Mashhad & Blood & 68 & 39 & 29 & $\mathrm{~F}$ & BRCA1 & $\mathrm{H}$ & $\begin{array}{l}\text { 185delAG, 5382insC, unclarified mutations in } \\
\text { the } 251 \text { bp fragment of exon } 11\end{array}$ & $(42)$ \\
\hline 4 & Kerman & Blood & 30 & - & - & $\mathrm{F} / \mathrm{M}$ & BRCA1 & $\mathrm{H}$ & $\begin{array}{l}\text { c. } 1017 \mathrm{del} A, \text { c. } 969 \text { InsC, c. } 999 \mathrm{~T}>\mathrm{A}, \text { c. } 792 \mathrm{~A}>\mathrm{C} \\
\text { c. } 825 \mathrm{G}>\mathrm{C}, \mathrm{c} .822 \mathrm{~T}>\mathrm{A}, \mathrm{c} .1068 \mathrm{~A}>\mathrm{G}, \mathrm{c} .969 \mathrm{~A}>\mathrm{T} \\
\mathrm{c.} .966 \mathrm{~T}>\mathrm{C}\end{array}$ & $(43)$ \\
\hline \multirow[t]{2}{*}{5} & \multirow[t]{2}{*}{ Isfahan } & \multirow[t]{2}{*}{ Blood } & \multirow[t]{2}{*}{61} & \multirow[t]{2}{*}{41} & \multirow[t]{2}{*}{20} & \multirow[t]{2}{*}{$\mathrm{F}$} & BRCA1 & \multirow[t]{2}{*}{$\mathrm{H}$} & 185 del AG, 5382 ins C, 1476 del G, 3889 del AG & \multirow[t]{2}{*}{$(44)$} \\
\hline & & & & & & & BRCA2 & & 6033-34 ins GT, 6174 del T & \\
\hline \multirow[t]{2}{*}{6} & \multirow[t]{2}{*}{ Tehran } & \multirow[t]{2}{*}{ Blood } & \multirow[t]{2}{*}{150} & \multirow[t]{2}{*}{100} & \multirow[t]{2}{*}{50} & \multirow[t]{2}{*}{$\mathrm{F}$} & BRCA1 & \multirow[t]{2}{*}{$\mathrm{H}$} & $\begin{array}{l}\text { p.Asn1403His, p.Gly1140Ser, p.lle26Val, } \\
\text { p.Leu1418X, p.Glu23GIn, p.Leu3X, } \\
\text { p.Asn1403Asp,p.Lys581X, p.Pro938Arg, } \\
\text { p.Thr77Arg, p.Leu6Val, p.Arg7Cys, p.Leu15lle, } \\
\text { p.Ser177Thr, IVS7 + 83(-TT), IVS8 -70(-CATT), } \\
\text { IVS2 + 9(G >C),IVS1-20(G > A), IVS1-8 A > G), } \\
\text { p.Met1Ile, IVS2 + 24(A > G),IVS5-8 (A > G), } \\
\text { IVS2(35-39)TTcctatGAT, IVS13 + 9 G >C }\end{array}$ & \multirow[t]{2}{*}{ (14) } \\
\hline & & & & & & & BRCA2 & & $\begin{array}{l}\text { p.Glu1391Gly, 1994-1995(InsA), IVS6-70(T > G) } \\
\text { p.Val1852lle }\end{array}$ & \\
\hline \multirow[t]{2}{*}{7} & \multirow[t]{2}{*}{ Tehran } & \multirow[t]{2}{*}{ Blood } & \multirow{2}{*}{$\begin{array}{l}5 \\
\text { families }\end{array}$} & \multirow[t]{2}{*}{-} & \multirow[t]{2}{*}{-} & \multirow[t]{2}{*}{$\mathrm{F}$} & BRCA1 & \multirow[t]{2}{*}{$\mathrm{H}$} & Misssense, Intronic Loss, New Mutation & $(45)$ \\
\hline & & & & & & & BRCA2 & & Misssense, Intronic Loss, New Mutation & \\
\hline 8 & Kermanshah & FFPE & 30 & - & - & $\mathrm{F}$ & BRCA1 & $\mathrm{H}$ & exon5, $11 \mathrm{~B}$ & $(46)$ \\
\hline 9 & Shiraz & Blood & 505 & 305 & 200 & $\mathrm{~F}$ & BRCA1 & $\mathrm{H}$ & 5382insC, 185delAG & $(47)$ \\
\hline & & & & & & & BRCA2 & & 6174delT & \\
\hline 10 & Mashhad & Blood & 142 & 42 & 100 & $\mathrm{~F}$ & BRCA1 exons & $\mathrm{H}$ & $\begin{array}{l}\text { was not present in the control families or BC- } \\
\text { free twin. }\end{array}$ & $(48)$ \\
\hline 11 & Tehran & Blood & 7 & 3 & 4 & $\mathrm{~F} / \mathrm{M}$ & BRCA2 & $\mathrm{H}$ & rs80359352 & $(49)$ \\
\hline 12 & Tehran & Blood & 87 & 67 & 20 & NA & BRCA2 & $\mathrm{H}$ & c.4415_4418delAGAA, c.6033_6034insGT & $(50)$ \\
\hline & & & & & & & BRCA1 & & g.5075-53C > T, g.*381_389del9ins29 & \\
\hline 13 & Shiraz & Blood & 1457 & - & 1057 & NA & CAT & $\mathrm{L}$ & C-262T (rs1001179) & (8) \\
\hline & Abarku & & & - & 200 & & & & & \\
\hline & Yasoj & & & - & 200 & & & & & \\
\hline 14 & Rafsanjan & Blood & 136 & 36 & 100 & $\mathrm{~F}$ & CCR5 & $\mathrm{L}$ & Mutation $\Delta 32$ & (51) \\
\hline 15 & Ahvaz & Tissue & 120 & 60 & 60 & NA & C-kit & $\mathrm{L}$ & Protein Expression & $(52)$ \\
\hline 16 & Isfahan & Blood & 190 & 90 & 100 & $\mathrm{~F}$ & Collagenase IV & $\mathrm{L}$ & $\mathrm{C} 1562 \mathrm{~T}$ & (53) \\
\hline 17 & Tabriz & Blood & 200 & 100 & 100 & $\mathrm{~F}$ & CYP1A1 & $\mathrm{L}$ & A2455G & $(54)$ \\
\hline 18 & Mashhad & Blood & 200 & 100 & 100 & $\mathrm{~F}$ & CYP2D6 & $\mathrm{L}$ & CYP2D $6 * 4$ (1846G to A) & $(55)$ \\
\hline 19 & Isfahan & Blood & 216 & 108 & 108 & $\mathrm{~F}$ & EGFR & $\mathrm{L}$ & $14,16,17,18,19,20,21$ repeats & $(56)$ \\
\hline 20 & Tehran & Tissue & 297 & 150 & 147 & $\mathrm{~F}$ & ER-a & 1 & A908G(K303R) & $(57)$ \\
\hline 21 & Tehran & Blood & 297 & 150 & 147 & $\mathrm{~F}$ & ER-a & $\mathrm{L}$ & codon325(CCC > CCG) & $(58)$ \\
\hline 22 & Tehran & Blood & 297 & 150 & 147 & $\mathrm{~F}$ & ESR1 exon 1 & $\mathrm{~L}$ & T 392 C & $(59)$ \\
\hline 23 & Tabriz & Blood & 200 & 100 & 100 & $\mathrm{~F}$ & FGFR2 & $\mathrm{L}$ & Rs1219684 & $(60)$ \\
\hline & & & & & & & Tp53 & $\mathrm{H}$ & Rs1042522 & \\
\hline 24 & Isfahan & Blood & 468 & 206 & 262 & $\mathrm{~F}$ & GATA3 & $\mathrm{L}$ & CT Dinucleotide Repeat in intron 3 & $(61)$ \\
\hline 25 & Ilam & Blood & 77 & 31 & 46 & $\mathrm{~F}$ & GST & $\mathrm{L}$ & GSTM1-null, GSTT1-null, GSTP1 & $(62)$ \\
\hline 26 & Zahedan & Blood & 286 & 134 & 152 & $\mathrm{~F}$ & GSTM1 & I & Null Genotype & $(63)$ \\
\hline
\end{tabular}




\begin{tabular}{|c|c|c|c|c|c|c|c|c|c|c|}
\hline No. & $\begin{array}{l}\text { City of } \\
\text { Study }\end{array}$ & $\begin{array}{l}\text { Type } \\
\text { of } \\
\text { sample }\end{array}$ & $\begin{array}{l}\text { Total } \\
\text { Sample } \\
\text { Size }\end{array}$ & Case & Ctrl & Sex & $\begin{array}{l}\text { Gene /Protein } \\
\text { Name }\end{array}$ & PG & GENE/Protein Alterations & Ref. \\
\hline & & & & & & & GSTP1 & & IleVal and ValVal Genotypes & \\
\hline & & & & & & & GSTT1 & & Null Genotype & \\
\hline 27 & Shiraz & Blood & 212 & 106 & 106 & $\mathrm{~F}$ & GSTZ1 & L & G-1002A, Gly42Arg Polymorphism & (64) \\
\hline 28 & Shiraz & Blood & 175 & 89 & 86 & $\mathrm{~F}$ & HLA & L & HLA-A24, HLA-A1 & (65) \\
\hline 29 & Tehran & Blood & 180 & 100 & 80 & $\mathrm{~F}$ & HLA-class II & L & DRB/DQA1/DQB1 & (66) \\
\hline \multirow[t]{4}{*}{30} & \multirow[t]{4}{*}{ Zahedan } & \multirow[t]{4}{*}{ Blood } & \multirow[t]{4}{*}{439} & \multirow[t]{4}{*}{236} & \multirow[t]{4}{*}{203} & \multirow[t]{4}{*}{$\mathrm{F}$} & hsa-miR-146a & \multirow[t]{4}{*}{ L } & rs2910164 G >C & \multirow[t]{4}{*}{ (67) } \\
\hline & & & & & & & hsa-miR-499 & & rs3746444 T >C & \\
\hline & & & & & & & hsa-miRNA-196a2 & & rs11614913 C>T & \\
\hline & & & & & & & hsa-miRNA-196a2 & & rs $185070757 \mathrm{~T}>\mathrm{G}$ & \\
\hline 31 & Isfahan & Blood & 200 & 100 & 100 & $\mathrm{~F}$ & IGF1 & L & allell $11,16,17,18,19,20,21,22,23$ & (68) \\
\hline \multirow[t]{4}{*}{32} & Tehran & Blood & 455 & - & 140 & \multirow[t]{4}{*}{$\mathrm{F} / \mathrm{M}$} & IL-1a, IL-1 $\beta$, IL-1 & \multirow[t]{4}{*}{ L } & \multirow{4}{*}{$\begin{array}{l}\text { C-889T, C-511T, C3962T, CPst-11970T, CMspa-I } \\
\text { 11100T, A-308G, A-238G, A-1188C, C-174G, A } \\
\text { nt565G, G-330T, G166T, AUTR5644T, G-1098T, } \\
\text { C-590T, C-33T, A1902G, A-1082G, C-819T, A- } \\
\text { 592C, C Codon } 10 \text { T, C Codon 25 G }\end{array}$} & \multirow[t]{4}{*}{$(69$} \\
\hline & Yazd & & & - & 121 & & $\begin{array}{l}\text { 6, IL-6, IL-2, IL-2, } \\
\text { IFN-y, IL-4, IL-4, IL- }\end{array}$ & & & \\
\hline & Sistan & & & - & 98 & & & & & \\
\hline & Balochistan & & & - & 96 & & $\begin{array}{l}\text { 4, IL-4RA, IL-10,IL- } \\
10, \text { IL-10, TGF- } \beta \text {, } \\
\text { TGF- } \beta\end{array}$ & & & \\
\hline 33 & Shiraz & Blood & 320 & 203 & 117 & $\mathrm{~F}$ & Leptin & L & G-2548A & (70) \\
\hline 34 & Mashhad & Blood & 183 & 106 & 77 & $\mathrm{~F}$ & MDR1 & L & С3435T & (71) \\
\hline 35 & Tehran & Blood & 94 & 54 & 40 & $\mathrm{~F}$ & MDR1 & L & С3435T & (72) \\
\hline 36 & $\begin{array}{l}\text { Kermanshah } \\
\text { \& llam }\end{array}$ & Tissue & 100 & 50 & 50 & NA & mt tRNAPhe/Pro & L & $\begin{array}{l}\text { C182T, 194insT, 285insA, 16342delT, 302insC, } \\
\text { C309T, C16069T }\end{array}$ & (73) \\
\hline 37 & Tehran & Blood & 592 & 282 & 310 & NA & MTR & 1 & A2756G & (74) \\
\hline 38 & Shahrekord & Blood & 275 & 135 & 140 & NA & p53 & $\mathrm{H}$ & Arg72Pro(Codon 72 exon 4) & (75) \\
\hline 39 & Tabriz & Tumor & 102 & 102 & - & NA & P53 & $\mathrm{H}$ & $\begin{array}{l}\text { codon160(ATG > AAG)exon5, codon163(ATC > } \\
\text { AAG) exon5, codon193(CAT > } \\
\text { AAT), codon195(ATC > TTC), codon195(ATC > } \\
\text { AAC), codon198(GAA > TAA), codon220(TAT > } \\
\text { TGT), codon213(CGA > CTA), codon214(CAT > } \\
\text { CGT) }\end{array}$ & (76) \\
\hline 40 & Isfahan & $\begin{array}{l}\text { Tissue } \\
\& \\
\text { Blood }\end{array}$ & 192 & 96 & 96 & $\mathrm{~F}$ & p53 & $\mathrm{H}$ & codon 72 (Arg/Arg,Pro/Pro,Arg/Pro) & (77) \\
\hline 41 & Tabriz & Tissue & 391 & 221 & 170 & $\mathrm{~F}$ & p53 & $\mathrm{H}$ & intron 3, 16 bp Polymorphism & (78) \\
\hline 42 & Tehran & Blood & 92 & 49 & 43 & $\mathrm{~F}$ & PTEN & $\mathrm{H}$ & IVS4 & (79) \\
\hline 43 & Tehran & Tissue & 137 & 137 & - & $\mathrm{F}$ & RARß2 \& ERa & L & hypermethylation frequencies & (80) \\
\hline 44 & Shiraz & Blood & 459 & 278 & 181 & $\mathrm{~F}$ & SDF-1 & L & A30G & (81) \\
\hline 45 & Tabriz & Tissue & 35 & 18 & 17 & $\mathrm{~F}$ & Survivin & L & Survivin, Survivin $\Delta \mathrm{Ex} 3$, Survivin $3 \mathrm{~b}$, Survivin $2 \mathrm{~b}$ & (82) \\
\hline 46 & Shiraz & Blood & 220 & 110 & 110 & $\mathrm{~F}$ & TGF $\beta 1$ & L & haplotypes "GTGCCGC" AND “GCGCCGC" & (83) \\
\hline 47 & Tabriz & Blood & 225 & 126 & 99 & $\mathrm{~F}$ & TP53 & $\mathrm{H}$ & codon72 Arg/Pro & (84) \\
\hline 48 & Tehran & Blood & 296 & 140 & 156 & $\mathrm{~F}$ & VDR & L & Fokl (FF, ff, Ff), Bsml (BB, bb, Bb) & (85) \\
\hline 49 & Tabriz & $\begin{array}{l}\text { Blood } \\
\& \\
\text { Tissue }\end{array}$ & 409 & 206 & 203 & $\mathrm{~F}$ & WRAP53 & L & rs2287499 & (86) \\
\hline 50 & Shiraz & Blood & 373 & 186 & 187 & $\mathrm{~F}$ & XRCC1 & L & Arg399Gln & (87) \\
\hline
\end{tabular}




\begin{tabular}{|c|c|c|c|c|c|c|c|c|c|c|}
\hline NO. & $\begin{array}{l}\text { City of } \\
\text { Study }\end{array}$ & $\begin{array}{l}\text { Type } \\
\text { of } \\
\text { sample }\end{array}$ & $\begin{array}{l}\text { Total } \\
\text { Sample } \\
\text { Size }\end{array}$ & Case & Ctrl & Sex & $\begin{array}{l}\text { Gene /Protein } \\
\text { Name }\end{array}$ & PG & GENE/Protein Alterations & Ref. \\
\hline \multirow[t]{2}{*}{51} & \multirow[t]{2}{*}{ Shiraz } & \multirow[t]{2}{*}{ Blood } & \multirow[t]{2}{*}{802} & \multirow[t]{2}{*}{407} & \multirow[t]{2}{*}{395} & \multirow[t]{2}{*}{$\mathrm{F}$} & XRCC5 & \multirow[t]{2}{*}{$\mathrm{L}$} & VNTR & \multirow[t]{2}{*}{ (88) } \\
\hline & & & & & & & XRCC6 & & T-991C & \\
\hline 52 & Shiraz & Blood & 724 & 362 & 362 & $\mathrm{~F}$ & XRCC7 G6721T & 1 & rs7003908 & (89) \\
\hline 53 & Tehran & $\begin{array}{l}\text { Blood } \\
\& \\
\text { Tissue }\end{array}$ & 85 & 50 & 35 & NA & DBC2 & $\mathrm{L}$ & methylation & $(90)$ \\
\hline 54 & Isfahan & Tissue & 73 & 53 & 20 & NA & PTEN & $\mathrm{H}$ & promoter methylation & (91) \\
\hline \multirow[t]{3}{*}{55} & \multirow[t]{3}{*}{ Tehran } & \multirow[t]{3}{*}{ Blood } & \multirow[t]{3}{*}{113} & \multirow[t]{3}{*}{63} & \multirow[t]{3}{*}{50} & \multirow[t]{3}{*}{$\mathrm{F}$} & BRCA1 & \multirow[t]{3}{*}{$\mathrm{H}$} & $\begin{array}{l}\text { Gly1140Ser, lleu15leu, lleu26leu, Glu23GIn, } \\
\text { Leu3stop codon, Pro9Arg, Leu6Val, Arg7Cys, } \\
\text { Ser177Val, }\end{array}$ & \multirow[t]{3}{*}{ (92) } \\
\hline & & & & & & & & & $\begin{array}{l}\text { IVS7 + 83(TT), IVS8 -70(CATT), IVS2 + 9(GC), } \\
\text { IVS1-20(GA), IVS1-8(AG), IVS2 + 24(AG) }\end{array}$ & \\
\hline & & & & & & & BRCA2 & & Glu1391Gly & \\
\hline 56 & $\begin{array}{l}\text { Kermanshah } \\
\text { and Ilam }\end{array}$ & Blood & 205 & 101 & 104 & $\mathrm{~F} / \mathrm{M}$ & MMP-9 & $\mathrm{L}$ & Promoter Polymorphism at C-1562T & (93) \\
\hline 57 & Zahedan & Blood & 165 & 72 & 93 & $\mathrm{~F}$ & IL-18 & $\mathrm{L}$ & IL-18 - 607 C/A Polymorphism & $(63)$ \\
\hline 58 & Tehran & Blood & 150 & 100 & 50 & NA & BRCA1/2 & $\mathrm{H}$ & Multiple Mutation & $(94)$ \\
\hline 59 & Tabriz & Blood & 190 & 95 & 95 & $\mathrm{~F}$ & MDM2 & $\mathrm{L}$ & 309T/G Polymorphism & $(95)$ \\
\hline 60 & Ahvaz & $\begin{array}{l}\text { Cell } \\
\text { Lines }\end{array}$ & 1 & 1 & - & NA & IL23, IL27 & $\mathrm{L}$ & Downregulation & $(96)$ \\
\hline 61 & Tehran & $\begin{array}{l}\text { Cell } \\
\text { Lines }\end{array}$ & - & - & - & - & Aurora-C & $\mathrm{L}$ & Overexpression/ Amplification & (97) \\
\hline 62 & Shiraz & $\begin{array}{l}\text { Cell } \\
\text { Lines }\end{array}$ & - & - & - & - & $\begin{array}{l}\text { Heme Oxygenase- } \\
1\end{array}$ & $\mathrm{~L}$ & Overexpression & (98) \\
\hline
\end{tabular}

Thirteen studies focused on BRCA $1 / 2$ genes. The total sample size in these studies was 1413 cases and controls and five families. While six studies determined the sequencing of all the exons of these two genes, the others examined their specific areas. P53, from the high-penetrance group of genes, was also observed in six studies. Few (mainly one) studies assessed other genes. The largest sample size (1457 participants) belonged to a study on the CAT gene (8).

The majority of studies were conducted in Tehran $(n=18)$, Shiraz $(n=11)$, and Tabriz $(n=8)$. None of the studies investigated the survival rate of mutation carriers.

\section{Prognosis, survival and clinicopathologic features}

Another group of studies investigated the relationship of gene or miRNA expressions, mutations, and epigenetic changes with clinicopathological characteristics and invasiveness of the disease (Table 2). The majority of these studies compared the tumor tissue with the adjacent healthy tissue. Most studies focused on the relationship of these genes with clinicopathological features of the tumor. Such features included stage, grade, tumor size, number of affected lymph nodes, and invasiveness of the disease. Moreover, 35 studies examined the expression of mRNA and proteins, nine assessed nucleotide changes in genes, one assessed the expression of miRNAs, two investigated immune cells, and three examined epigenetic modifications and their relationship with clinicopathological features of the disease. There was a significant relationship between the age of diagnosis and the expression of six genes (HER2, BRCA1, P53, RARß2, PR, ER). Tumor size was also significantly related to the expression of five genes and/or proteins (EMSY, MYC, HER2, TOP2A, CD10). Natural killer (NK) cells, catalase and superoxide dismutase activity, and expression of mir21, P53, Ki67, E-cadherin, and BRCA1 were found to have significant relationships with the stage of the disease. Twelve studies identified significant associations between tumor grade and 22 genes/proteins including Bcl-2, $\mathrm{E}-$ cadherin, FGFR1, ADAM9, IKBKB, PRDM14, MTDH, MYC, HER2, CCND1, TOP2A, CDC6, CD10, BRCA 1,hTERT,p53, PSA, Telomerase, Hsp70, HER2, MHC I and ICAM-I (9-20). 
Table 2

Studies focusing on genes related to prognosis, survival and clinicopathologic $f_{1}$

\begin{tabular}{|c|c|c|c|c|c|c|c|c|c|c|c|c|c|c|c|}
\hline NO. & $\begin{array}{l}\text { Gene /Protein } \\
\text { name }\end{array}$ & $\begin{array}{l}\text { GENE/Protein } \\
\text { Alterations }\end{array}$ & $\begin{array}{l}\text { city of } \\
\text { study }\end{array}$ & Type of sample & $\begin{array}{l}\text { total } \\
\text { sample } \\
\text { size }\end{array}$ & Case & control & sex & Age & A & B & C & D & $E$ & F $\quad G$ \\
\hline 1 & $\begin{array}{l}\text { Chromosome } \\
17\end{array}$ & Aneusomy & Tehran & Tissue & 30 & * & * & $\mathrm{F}$ & & & & & & & * \\
\hline 2 & $($ HER-2)/ neu & $\begin{array}{l}\text { Over } \\
\text { expression }\end{array}$ & Mashhad & Tissue & 196 & 196 & non & $\mathrm{F}$ & * & & & & & & \\
\hline 3 & EMSY protein & $\begin{array}{l}\text { Expression } \\
\text { and } \\
\text { localization }\end{array}$ & Tehran & Tissue & 116 & 116 & non & $\mathrm{F}$ & & * & & & & & \\
\hline 4 & $\mathrm{Bcl}-2$ & $\begin{array}{l}\text { Over } \\
\text { expression }\end{array}$ & Tabriz & Tissue & 40 & 21 & 19 & NA & & & & * & & & \\
\hline 5 & $\begin{array}{l}\text { GSTT1, } \\
\text { GSTM1, } \\
\text { GSTZ1, and } \\
\text { GSTO2 } \\
\text { (detoxifying } \\
\text { genes) } \\
\text { XRCC1, } \\
\text { XRCC6 and } \\
\text { XRCC7 (DNA } \\
\text { repair genes) }\end{array}$ & $\begin{array}{l}\text { Poly } \\
\text { morphisms }\end{array}$ & Shiraz & & 101 & & non & & & & & & & & \\
\hline 6 & $\begin{array}{l}\text { MMP-9 } \\
\text { promoter } \\
\text { polymorphism }\end{array}$ & $\begin{array}{l}(\mathrm{C}-1562 \mathrm{~T}) \\
\text { poly } \\
\text { morphism }\end{array}$ & Isfahan & Blood & 280 & 180 & 100 & $\mathrm{~F}$ & & & & & & & \\
\hline \multirow[t]{2}{*}{7} & ATM & $\begin{array}{l}\text { Down } \\
\text { regulation }\end{array}$ & Tehran & Tissue & 129 & 119 & 10 & $\mathrm{~F}$ & & & & & & & \\
\hline & cyclin D1 & $\begin{array}{l}\text { Over } \\
\text { expression }\end{array}$ & & & & & & & & & & & & & \\
\hline \multirow[t]{2}{*}{8} & MiR-21 & $\begin{array}{l}\text { Over } \\
\text { expression }\end{array}$ & Tehran & Tissue & 59 & 59 & * & NA & & & & & & & * \\
\hline & $\begin{array}{l}\text { MiR-342 and } \\
\text { MiR-205 }\end{array}$ & $\begin{array}{l}\text { Down } \\
\text { regulation }\end{array}$ & & & & & & & & & & & & & \\
\hline 9 & $\begin{array}{l}\text { UBE2Q1 } \\
\text { (ubiquitin- } \\
\text { conjugating } \\
\text { enzyme E2Q } \\
\text { family } \\
\text { member 1) }\end{array}$ & $\begin{array}{l}\text { Over } \\
\text { expression }\end{array}$ & Shiraz & Tissue specimens & 26 & 26 & non & $\mathrm{F}$ & & & & & & & \\
\hline 10 & UBE2Q1 & $\begin{array}{l}\text { Over } \\
\text { expression }\end{array}$ & Shiraz & $\begin{array}{l}\text { MDA-MB-468 } \\
\text { cell line }\end{array}$ & * & * & * & * & & & & & & & \\
\hline 11 & $\begin{array}{l}\text { E-cadherin } \\
(\mathrm{CDH} 1)\end{array}$ & $\begin{array}{l}\text { Down } \\
\text { regulation by } \\
\text { promoter } \\
\text { methylation }\end{array}$ & Tabriz & tissue samples & 100 & 50 & 50 & $\mathrm{~F}$ & & & & * & & & * \\
\hline \multirow[t]{3}{*}{12} & $\begin{array}{l}\text { Bcl-2/Bax } \\
\text { Ratio }\end{array}$ & Increase & Tabriz & $\begin{array}{l}\text { Tow } \\
\text { paclitaxelresistance }\end{array}$ & * & * & * & * & & & & & * & & \\
\hline & Caspase-8 & Increase & & & & & & & & & & & * & & \\
\hline & Caspase-9 & Decrease & & & & & & & & & & & * & & \\
\hline 13 & $\begin{array}{l}\text { CCND1, HER2 } \\
\text { AND AIB1 }\end{array}$ & $\begin{array}{l}\text { Over } \\
\text { expression }\end{array}$ & Tehran & Tissue & 170 & 85 & 85 & $\mathrm{~F}$ & & & & & & & \\
\hline
\end{tabular}




\begin{tabular}{|c|c|c|c|c|c|c|c|c|c|c|c|c|c|c|c|c|}
\hline NO. & $\begin{array}{l}\text { Gene /Protein } \\
\text { name }\end{array}$ & $\begin{array}{l}\text { GENE/Protein } \\
\text { Alterations }\end{array}$ & $\begin{array}{l}\text { city of } \\
\text { study }\end{array}$ & Type of sample & $\begin{array}{l}\text { total } \\
\text { sample } \\
\text { size }\end{array}$ & Case & control & $\operatorname{sex}$ & Age & A & B & C & D & $E$ & $\mathbf{F}$ & G \\
\hline & NCOR1 & $\begin{array}{l}\text { Down } \\
\text { regulation }\end{array}$ & & & & & & & & & & & & & & \\
\hline \multirow[t]{3}{*}{14} & $\begin{array}{l}\text { FGFR1, } \\
\text { ADAM9, } \\
\text { IKBKB, } \\
\text { PRDM14, } \\
\text { MTDH, MYC, } \\
\text { HER2, }\end{array}$ & amplification & Tehran & FFPE tumor blocks & 170 & 85 & 85 & $\mathrm{~F}$ & & & & * & & & & \\
\hline & $\begin{array}{l}\text { CCND1, } \\
\text { TOP2A }\end{array}$ & amplification & & & & & & & & & & * & & & & \\
\hline & CDC6 & amplification & & & & & & & & & & * & & & & \\
\hline 15 & CD10 & Expression & Mashhad & paraffin blocks & 150 & 100 & 50 & & & * & & * & & & & \\
\hline \multirow[t]{2}{*}{16} & MDR1 & Expression & Tehran & Tissue & 54 & 54 & non & $\mathrm{F}$ & & & & & & & & \\
\hline & MRP1 & Expression & & & & & & & & & & & & & & \\
\hline 17 & MDR1 & $\begin{array}{l}\text { Poly } \\
\text { morphism }\end{array}$ & Tehran & $\begin{array}{l}\text { Tissue \& } \\
\text { Blood }\end{array}$ & 104 & 54 & 50 & $\mathrm{~F}$ & & & & & * & & & \\
\hline 18 & $\begin{array}{l}\text { ST6Gal1, Cox- } \\
2 \text {, HB-EGF }\end{array}$ & $\begin{array}{l}\text { Over } \\
\text { expression }\end{array}$ & Kashan & Tissue & 108 & 54 & 54 & & & & & & & & & \\
\hline 19 & P16ink4a & $\begin{array}{l}\text { Promoter } \\
\text { methylation }\end{array}$ & Isfahan & Blood & 140 & 70 & 70 & $\mathrm{~F}$ & * & & * & & & & * & \\
\hline 20 & MUC2 & $\begin{array}{l}\text { Over } \\
\text { expression }\end{array}$ & Tehran & $\begin{array}{l}\text { Blood, } \\
\text { Bone marrow }\end{array}$ & 70 & 50 & 20 & $\mathrm{~F} / \mathrm{M}$ & & & & & & & & \\
\hline 21 & BRCA 1 & $\begin{array}{l}\text { Down } \\
\text { regulation }\end{array}$ & $\begin{array}{l}\text { Tehran, } \\
\text { Ardebil }\end{array}$ & Tumor samples & 27 & 27 & non & $\mathrm{F}$ & & & & * & & & & \\
\hline 22 & BRCA 1 & $\begin{array}{l}\text { Down } \\
\text { regulation, } \\
\text { Localization }\end{array}$ & Tehran & Tumor & 156 & 156 & non & $\mathrm{F}$ & * & & * & * & & & & \\
\hline 23 & hTERT & $\begin{array}{l}\text { Over } \\
\text { expression }\end{array}$ & Tabriz & $\begin{array}{l}\text { Blood and } \\
\text { Tumor }\end{array}$ & 65 & 65 & non & $\mathrm{F}$ & & & & * & & & * & \\
\hline 24 & IL-12 & $\begin{array}{l}\text { Over } \\
\text { expression }\end{array}$ & Tehran & Blood & 76 & 50 & 26 & NA & & & & & & & & \\
\hline & $\begin{array}{l}\text { CD4+ } \\
\text { lymphocyte }\end{array}$ & Decrease & & & & & & & & & & & & & & \\
\hline 25 & Gelatinase B & $\begin{array}{l}\text { Poly } \\
\text { morphism }\end{array}$ & Isfahan & Blood & 190 & 90 & 100 & $\mathrm{~F}$ & & & & & & & & \\
\hline 26 & MMP-9 & $\begin{array}{l}\text { Down } \\
\text { regulation }\end{array}$ & Isfahan & Blood & 98 & 98 & non & $\mathrm{F}$ & & & & & & & & \\
\hline 27 & MMP-3 & $\begin{array}{l}\text { Poly } \\
\text { morphism }\end{array}$ & Isfahan & Blood & 180 & 120 & 60 & $\mathrm{~F}$ & & & & & & & & \\
\hline 28 & p53 & expression & Rasht & Tissue samples & 465 & 465 & non & & * & & & * & & & & \\
\hline 29 & active MMP9 & $\begin{array}{l}\text { plasma } \\
\text { concentration }\end{array}$ & Isfahan & Blood & 220 & 100 & 120 & $\mathrm{~F}$ & & & & & & & & \\
\hline & & $\begin{array}{l}\text { Poly } \\
\text { morphism c-t }\end{array}$ & & & & & & & & & & & & & & \\
\hline
\end{tabular}




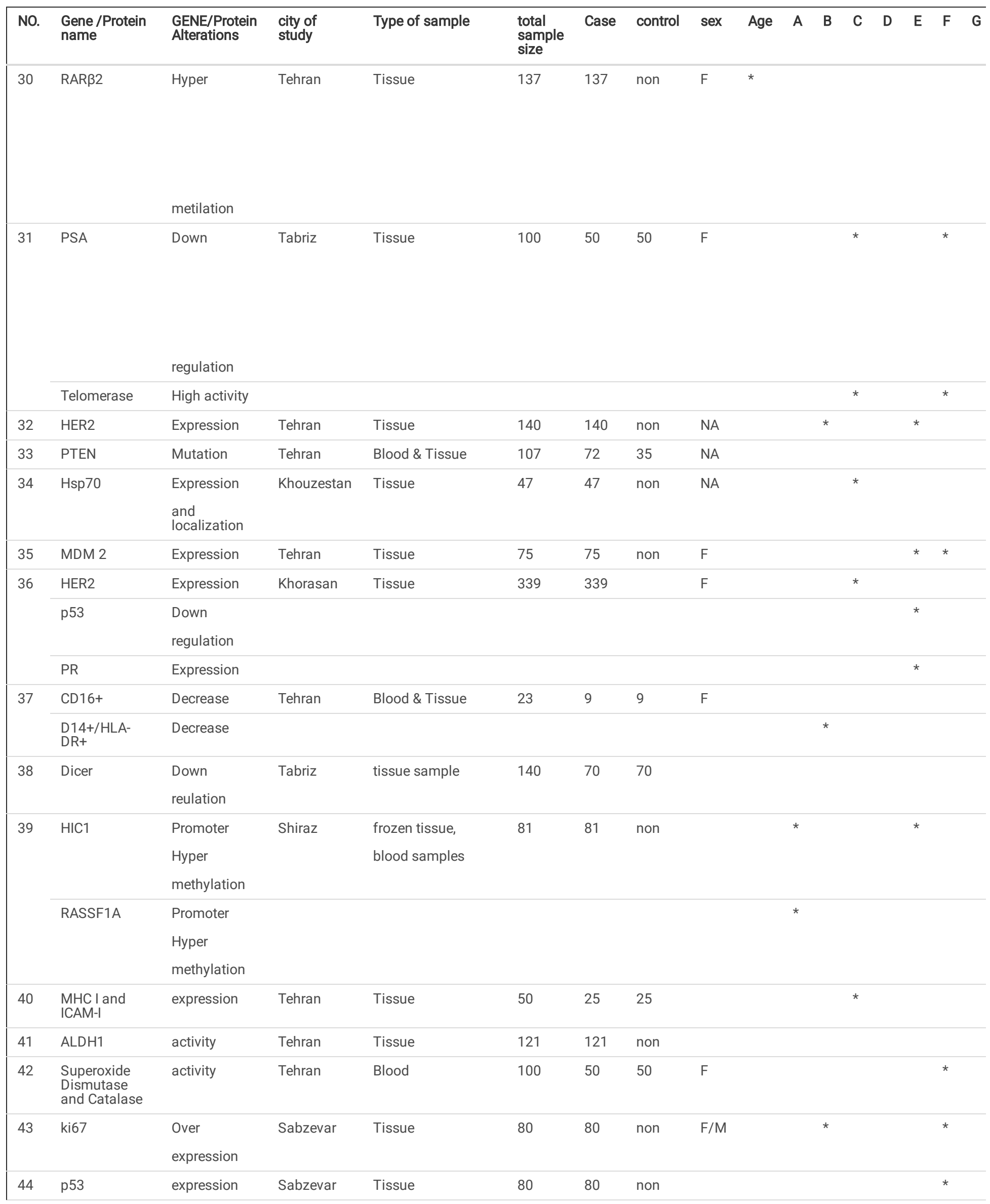




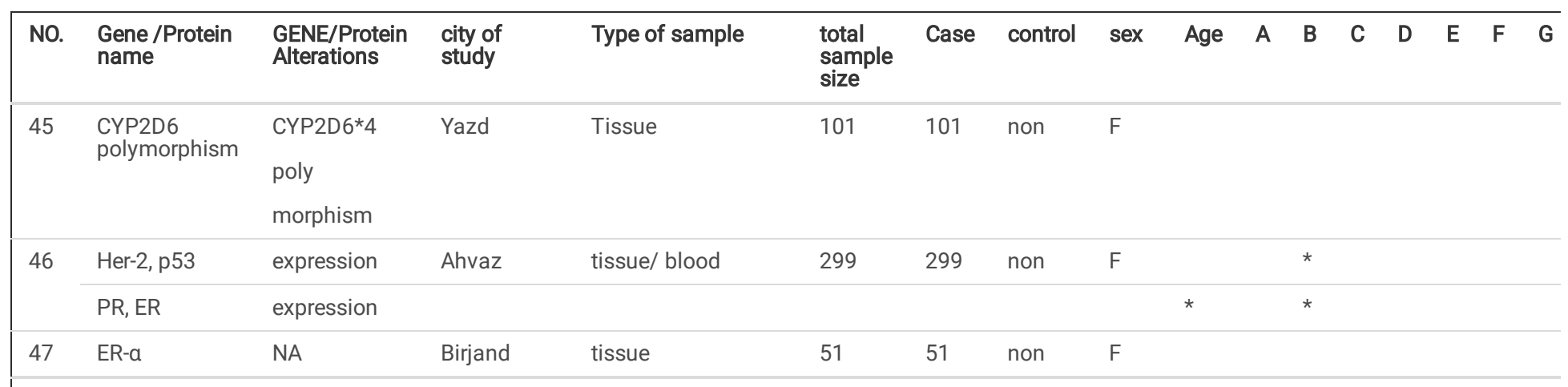

A: Tumor Size, B: Histological Type, C: Grade, D:Drug Resistance, E: Lymph Node Status, F: Stage, G: BC Occurrence, H: Occupation, I: Body Mass Index, J: Lef Status, Q: HER-2 Status, R: TNBC Status, S: Lymph Node Metastasis, T: Metastasis, U: Risk of Cancer, V: Recurrence on Tamoxifen Treatment, W: MAI, X: Fam

Seven studies also showed significant relationships between EMSY protein, MiR 21, CD 10, HER2, MDM2, P53, PR and HIC1 expression and number of affected lymph nodes $(12,19,21-25)$ ( The list of significant genes $(n=9)$ is shown in Table 2. The relationship between six genes including IL-12, Gelatinase B, MMP-9, MMP-3 and p53 and metastasis was significant in these studies $(19,26-30)$ Of the two studies evaluating the relationship between gene expression and response to chemotherapy; one found the relationship between MRP1and metastasis to be significant (31).

\section{Treatment}

The third group of studies focused on the therapeutic effects of different compounds, including herbal extracts, medicinal compounds, nanoparticles, and bacteria, on breast cancer (Table 3). Some of these studies $(n=104)$ assessed the effects of various compounds on the expression of specific genes involved in apoptosis or cell proliferation. The most studied compounds are drug conjugate to Trastuzumab and nanoparticle forms of doxorubicin (32-39). Of these, four were conducted on human samples and 20 on rats or mice (in-vivo). The studies mainly involved cells and cell lines (particularly MCF7). Most studies (n = 42) used MTT assay to determine the effects of various compounds on specific genes, mainly cell proliferation and apoptosis pathway genes. 
Table 3

Iranian studies focusing on herbal, microbial, chemical, or synthetic compounds with anticancer properties.

\begin{tabular}{|c|c|c|c|c|c|c|}
\hline No. & Type of Study & $\begin{array}{l}\text { Gene } \\
\text { /Protein/ Cell } \\
\text { Activity }\end{array}$ & Drug / Extract/ Component name & $\begin{array}{l}\text { Cell Line, Tissue, Animal } \\
\text { model name }\end{array}$ & Effect & Ref. \\
\hline \multirow[t]{2}{*}{1} & \multirow[t]{2}{*}{$\begin{array}{l}\text { Effect of } \\
\text { Components }\end{array}$} & & Astrodaucus persicus (Boiss.) Drude & T47D cell line & $\begin{array}{l}\text { Prolifration } \\
\downarrow \text { (insignificantly) }\end{array}$ & \multirow[t]{2}{*}{ (32) } \\
\hline & & & Doxorubicin & T47D cell line & Prolifration $\downarrow$ & \\
\hline 2 & $\begin{array}{l}\text { Effect of } \\
\text { Components }\end{array}$ & cyclin D1 & Crocin (from Crocus sativus L.) & Rats & $\downarrow$ Expression & (122) \\
\hline 3 & $\begin{array}{l}\text { Effect of } \\
\text { Components }\end{array}$ & & Marrubium persicum & MCF-7 cell line & Prolifration $\downarrow$ & (123) \\
\hline \multirow[t]{4}{*}{4} & \multirow{4}{*}{$\begin{array}{l}\text { New } \\
\text { Technologies }\end{array}$} & & trastuzumab-multiwalled carbon nanotubes & SK-BR-3 cell line & $\downarrow$ Cell viability & \multirow[t]{4}{*}{ (33) } \\
\hline & & & trastuzumab-multiwalled carbon nanotubes & MCF-7 cell line & $\begin{array}{l}\text { No effect on Cell } \\
\text { viability }\end{array}$ & \\
\hline & & & trastuzumab-diphtheria toxin & SK-BR-3 cell line & $\downarrow$ Cell viability & \\
\hline & & & trastuzumab-diphtheria toxin & MCF-7 cell line & $\begin{array}{l}\text { No effect on Cell } \\
\text { viability }\end{array}$ & \\
\hline 5 & $\begin{array}{l}\text { New } \\
\text { Technologies }\end{array}$ & & Silver Nanoparticles and lons & $\begin{array}{l}\text { Parent and tamoxifen- } \\
\text { resistant T47D cell lines }\end{array}$ & $\downarrow$ Cell viability & (124) \\
\hline 6 & $\begin{array}{l}\text { Effect of } \\
\text { Components }\end{array}$ & & Cadmium and Copper Chloride & MDA-MB468 cell line & $\downarrow$ Cell viability & (125) \\
\hline \multirow[t]{2}{*}{7} & \multirow[t]{2}{*}{$\begin{array}{l}\text { Effect of } \\
\text { Components }\end{array}$} & $\begin{array}{l}\text { BRCA1, ATM, } \\
\text { Bak, p53, p21 }\end{array}$ & \multirow[t]{2}{*}{ Silibinin } & \multirow[t]{2}{*}{ MCF7 Cell line } & $\begin{array}{l}\uparrow \text { Genes Expression, } \\
\downarrow \text { Cell Prolifration, } \uparrow \\
\text { Cell Apoptosis }\end{array}$ & \multirow[t]{2}{*}{$(126)$} \\
\hline & & $\mathrm{Bcl}-\mathrm{xl}$ & & & $\downarrow$ Gene Expression & \\
\hline \multirow[t]{2}{*}{8} & \multirow{2}{*}{$\begin{array}{l}\text { New } \\
\text { Technologies }\end{array}$} & & 2-(3,5-Dihydroxyphenyl) & \multirow[t]{2}{*}{ MDA-MB-231 } & \multirow{2}{*}{$\begin{array}{l}\uparrow \text { Apoptosis, Arrest of } \\
\text { Prolifration }\end{array}$} & \multirow[t]{2}{*}{$(127)$} \\
\hline & & & -6-hydroxybenzothiazole & & & \\
\hline 9 & $\begin{array}{l}\text { New } \\
\text { Technologies }\end{array}$ & & $\begin{array}{l}\text { Dimethyl-5-acetyl-4-methyl-6-(4- } \\
\text { methylphenylimino)-6H-thiopyran-2,3- } \\
\text { dicarboxylate }\end{array}$ & MCF-7 cell line & $\downarrow$ proliferation & (128) \\
\hline \multirow[t]{2}{*}{10} & \multirow[t]{2}{*}{$\begin{array}{l}\text { New } \\
\text { Technologies }\end{array}$} & & $\begin{array}{l}\text { A naphthalene-fused (a- } \\
\text { alkoxycarbonyl)methylene-g-butyrolactone } \\
\text { (methyl 2-[7-hydroxy-2-oxonaphtho[1,2- }\end{array}$ & \multirow[t]{2}{*}{ MCF-7 cell line } & \multirow[t]{2}{*}{$\downarrow$ proliferation } & \multirow[t]{2}{*}{ (129) } \\
\hline & & & b]furan-3(2H)-yliden]acetate) & & & \\
\hline \multirow[t]{2}{*}{11} & \multirow{2}{*}{$\begin{array}{l}\text { New } \\
\text { Technologies }\end{array}$} & & 2-(3,5-Dihydroxyphenyl)-6- & \multirow[t]{2}{*}{ MCF-7 cell line } & \multirow[t]{2}{*}{$\downarrow$ Proliferation } & \multirow[t]{2}{*}{$(130)$} \\
\hline & & & Hydroxybenzothiazole & & & \\
\hline 12 & $\begin{array}{l}\text { New } \\
\text { Technologies }\end{array}$ & & 177Lu-DOTA-trastuzumab & MCF-7 cell line & $\downarrow$ Cell viability & (34) \\
\hline 13 & $\begin{array}{l}\text { Effect of } \\
\text { Components }\end{array}$ & & 177Lu-DOTA-trastuzumab & $\begin{array}{l}\text { SKBr3 and MCF7 cell } \\
\text { lines }\end{array}$ & $\downarrow$ Cell viability & (35) \\
\hline 14 & $\begin{array}{l}\text { Effect of } \\
\text { Components }\end{array}$ & & Silimarin and Doxorubicin & MCF-7 cell line & $\uparrow$ Apoptosis & $(36)$ \\
\hline 15 & $\begin{array}{l}\text { Effect of } \\
\text { Components }\end{array}$ & & Baneh and Doxorubicin & T47D cell line & $\uparrow$ Apoptosis & $(37)$ \\
\hline \multirow[t]{2}{*}{16} & \multirow[t]{2}{*}{$\begin{array}{l}\text { Effect of } \\
\text { Components }\end{array}$} & $\begin{array}{l}\text { cyclin D1, } \\
\text { cdk4, CyclinA, } \\
\text { cdk2 }\end{array}$ & Baneh & T47D cell line & $\downarrow$ Expression & \multirow[t]{2}{*}{$(131)$} \\
\hline & & $\begin{array}{l}\text { Cyclin E, cdk1, } \\
\text { CyclinB1 }\end{array}$ & & & $\uparrow$ Expression & \\
\hline 17 & $\begin{array}{l}\text { Effect of } \\
\text { Components }\end{array}$ & & Crab Shell & MCF-7 cell line & $\begin{array}{l}\downarrow \text { Proliferation } \\
\text { ( } \uparrow \text { Apoptosis, } \downarrow \text { Nitric } \\
\text { oxide level) }\end{array}$ & (132) \\
\hline \multicolumn{7}{|c|}{ Web of Science, PubMed, Scopus, SID, IranMedex } \\
\hline $\operatorname{Jan} 2$ & 005-Oct2015 & & & & & \\
\hline 1986 & English Citation & & & & & \\
\hline 1345 & rsian Citatio & & & & & \\
\hline
\end{tabular}




\begin{tabular}{|c|c|c|c|c|c|c|}
\hline No. & Type of Study & $\begin{array}{l}\text { Gene } \\
\text { /Protein/ Cell } \\
\text { Activity }\end{array}$ & Drug /Extract/ Component name & $\begin{array}{l}\text { Cell Line, Tissue, Animal } \\
\text { model name }\end{array}$ & Effect & Ref. \\
\hline 18 & $\begin{array}{l}\text { Effect of } \\
\text { Components }\end{array}$ & Mre11 & Lithium chloride & T47D cell line & $\begin{array}{l}\downarrow \text { DNA repair, } \downarrow \\
\text { Expression }\end{array}$ & (133) \\
\hline 19 & $\begin{array}{l}\text { Effect of } \\
\text { Components }\end{array}$ & Mre11 & Lithium chloride & T47D cell line & $\begin{array}{l}\downarrow \text { DNA repair, } \downarrow \\
\text { Expression }\end{array}$ & (134) \\
\hline \multirow[t]{2}{*}{20} & \multirow{2}{*}{$\begin{array}{l}\text { Effect of } \\
\text { Components }\end{array}$} & & letulin and dexorubicin & MDA-MB 231 & $\uparrow$ Cell death & \multirow[t]{2}{*}{ (135) } \\
\hline & & $\begin{array}{l}\text { Nrf2, Ho1, } \\
\text { MDR1 }\end{array}$ & luteolin-loaded nanoparticles & & $\downarrow$ Expression & \\
\hline 21 & $\begin{array}{l}\text { Effect of } \\
\text { Components }\end{array}$ & & $\begin{array}{l}\text { Viola tricolor(EtOAc, } n \text {-butanol, and } \mathrm{H} 2 \mathrm{O} \\
\text { fractions and Hydroalcoholic extract ) }\end{array}$ & $\begin{array}{l}\text { Neuro2a mouse } \\
\text { neuroblastoma and } \\
\text { MCF-7 cell line and } \\
\text { normal L929 cells }\end{array}$ & $\begin{array}{l}\uparrow \text { Cell death, } \\
\uparrow \text { Apoptosis(caspase- } \\
\text { dependent) }\end{array}$ & (136) \\
\hline 22 & $\begin{array}{l}\text { Effect of } \\
\text { Components }\end{array}$ & & Metformin & $\begin{array}{l}\text { MCF-7, BT-474, SK-BR-3 } \\
\text { and MDA-MB-231 cell } \\
\text { lines +/_Paclitaxel }\end{array}$ & $\begin{array}{l}\text { No effect on Cell } \\
\text { viability and } \\
\text { paclitaxel } \\
\text { cytotoxicity }\end{array}$ & (137) \\
\hline \multirow[t]{3}{*}{23} & \multirow[t]{3}{*}{$\begin{array}{l}\text { Effect of } \\
\text { Components }\end{array}$} & & ZnO nanoparticles & $\begin{array}{l}\text { Du145 and T-47D cell } \\
\text { lines }\end{array}$ & $\begin{array}{l}\text { Significant lethal } \\
\text { effects }\end{array}$ & \multirow[t]{3}{*}{ (138) } \\
\hline & & & ZnO-MTCP and ZnO-CuMTCP & $\begin{array}{l}\text { Du145 and T-47D cell } \\
\text { lines }\end{array}$ & No cytotoxic effects & \\
\hline & & & ZnO-MTCP + UV light exposure & T-47D cell line & $\downarrow$ Survival & \\
\hline 24 & $\begin{array}{l}\text { Effect of } \\
\text { Components }\end{array}$ & & palladium(II) complex $+/$ - calf thymus DNA & T-47D cell line & $\downarrow$ Cell proliferation & (139) \\
\hline 25 & $\begin{array}{l}\text { Effect of } \\
\text { Components }\end{array}$ & & $\begin{array}{l}\text { AuNP-Conjugated/ Non-conjugated 2-amino- } \\
\text { 4H-chromene-3-carbonitrile }\end{array}$ & T-47D cell line & $\downarrow$ Cell viability & $(140)$ \\
\hline 26 & $\begin{array}{l}\text { Effect of } \\
\text { Components }\end{array}$ & & Noscapine and papaverine & $\begin{array}{l}\text { MCF-7 and MDA-MB- } \\
231 \text { cell lines }\end{array}$ & $\uparrow$ Apoptosis of CSCs & $(141)$ \\
\hline 27 & $\begin{array}{l}\text { Effect of } \\
\text { Components }\end{array}$ & & $\begin{array}{l}\text { (1)polypyridyl-based copper(II) complexes } \\
\text { [Cu(tpy)(dppz)](NO3)2 and (2)polypyridyl- } \\
\text { based copper(II) complexes [Cu(tptz)2](NO3)2 }\end{array}$ & MCF-7 cell line & $\uparrow$ Apoptosis & (142) \\
\hline 28 & $\begin{array}{l}\text { Effect of } \\
\text { Components }\end{array}$ & & ethanolic extract of Alpinia galanga rhizhome & MCF-7 cell line & $\downarrow$ Cell viability & (143) \\
\hline 29 & Biomarkers & PDE9 & inhibitor BAY 73-6691 & $\begin{array}{l}\text { MCF-7 and MDA-MB- } \\
468 \text { cell lines }\end{array}$ & $\begin{array}{l}\downarrow \text { Expression, } \downarrow \text { cell } \\
\text { proliferation, } \\
\uparrow \text { Apoptosis }\end{array}$ & (144) \\
\hline 30 & $\begin{array}{l}\text { Effect of } \\
\text { Components }\end{array}$ & Survivin & Piperine & $\begin{array}{l}\text { Triple-negative breast } \\
\text { cancer cells in vitro and } \\
\text { in vivo }\end{array}$ & $\begin{array}{l}\text { Inhibition of Survivin, } \\
\uparrow \text { Apoptosis }\end{array}$ & (145) \\
\hline 31 & $\begin{array}{l}\text { Effect of } \\
\text { Components }\end{array}$ & & $\begin{array}{l}\text { Mitoxantrone }(\mathrm{MX})+\text { ionizing radiation and } \\
\text { photodynamic therapy }\end{array}$ & MCF-7 cell line & $\begin{array}{l}\uparrow \text { Cell death, } \downarrow \text { Cell } \\
\text { viability }\end{array}$ & $(146)$ \\
\hline \multirow[t]{5}{*}{32} & \multirow[t]{5}{*}{ Biomarkers } & FBX039 & & MCF-7 cell line & Expressed & \multirow[t]{5}{*}{ (147) } \\
\hline & & $\begin{array}{l}\text { TDRD4, } \\
\text { FBX039 }\end{array}$ & & MDA-MB-231 cell line & Expressed & \\
\hline & & FBX039 & RHOXF1 shRNA & $\begin{array}{l}\text { invasive ductal } \\
\text { carcinoma samples and } \\
\text { MDA-MB-231 cell line }\end{array}$ & $\uparrow$ Expression & \\
\hline & & FBX039 & RHOXF1 shRNA & MCF-7 cell line & $\downarrow$ Expression & \\
\hline & & TDRD4 & RHOXF1 shRNA & MDA-MB-231 cell line & $\uparrow$ Expression & \\
\hline 33 & $\begin{array}{l}\text { Effect of } \\
\text { Components }\end{array}$ & & $\begin{array}{l}\text { SN38 (7-ethyl-10-hydroxyl camptothecin) and } \\
\text { SN38-NPs }\end{array}$ & $\begin{array}{l}4 \mathrm{~T} 1 \text { breast cancer cells } \\
\text { and xenograft balb/c } \\
\text { animal }\end{array}$ & $\uparrow$ Cytotoxicity & (148) \\
\hline
\end{tabular}

Web of Science, PubMed, Scopus, SID, IranMedex

Jan 2005-Oct2015

1986 English Citation(s)

1345 Persian Citation(s) 


\begin{tabular}{|c|c|c|c|c|c|c|}
\hline No. & Type of Study & $\begin{array}{l}\text { Gene } \\
\text { /Protein/ Cell } \\
\text { Activity }\end{array}$ & Drug /Extract/ Component name & $\begin{array}{l}\text { Cell Line, Tissue, Animal } \\
\text { model name }\end{array}$ & Effect & Ref. \\
\hline \multirow[t]{4}{*}{34} & $\begin{array}{l}\text { Effect of } \\
\text { Components }\end{array}$ & & $\begin{array}{l}\text { Myrsinane-type compounds: 3,7,14,15- } \\
\text { tetraacetyl-5-propanoyl-13(17)-epoxy-8,10(18)- } \\
\text { myrsinadiene (1) and 3,7,10,14,15-pentaacetyl- } \\
\text { 5-butanoyl-13,17-epoxy-8- }\end{array}$ & \multirow[t]{4}{*}{$\begin{array}{l}\text { MCF-7 and MDA-MB } \\
468 \text { cell lines }\end{array}$} & $\begin{array}{l}\text { Moderate } \\
\text { Cytotoxicity }\end{array}$ & \multirow[t]{4}{*}{ (149) } \\
\hline & & & myrsinene (2) & & & \\
\hline & & & $\begin{array}{l}\text { Jatrophane-type diterpene: 5,6-epoxy-8,9,15- } \\
\text { triacetyl-3- }\end{array}$ & & Weak Cytotoxicity & \\
\hline & & & benzoyl-14-oxo-jatropha-11(E)-ene (3) & & & \\
\hline 35 & $\begin{array}{l}\text { Effect of } \\
\text { Components }\end{array}$ & & $\begin{array}{l}\text { artemisinin + Miconazole + Butyric acid + Iron } \\
\text { sulfate }\end{array}$ & $4 \mathrm{~T} 1$ breast cancer cells & $\uparrow$ Apoptosis & $(150)$ \\
\hline 36 & $\begin{array}{l}\text { Effect of } \\
\text { Components }\end{array}$ & & pegylated liposomal trans-anethole & $\begin{array}{l}\text { MCF-7 and T47D cell } \\
\text { lines }\end{array}$ & $\uparrow$ Cytotoxicity & (151) \\
\hline 37 & $\begin{array}{l}\text { New } \\
\text { Technologies }\end{array}$ & $\begin{array}{l}\text { Th1, Th2 and } \\
\text { Treg }\end{array}$ & (TNF-a/CD40L)-MSCs + DCs & $\begin{array}{l}4 \mathrm{~T} 1 \text { injected BALB/c } \\
\text { mouse }\end{array}$ & $\begin{array}{l}\downarrow \text { Expression, } \downarrow \text { Tumor } \\
\text { progression, } \uparrow \text { Survival }\end{array}$ & $(152)$ \\
\hline 38 & $\begin{array}{l}\text { Effect of } \\
\text { Components }\end{array}$ & HER-2 & recombinant $\lambda$ phage $\mathrm{C}$-Myc tagged & $\begin{array}{l}\text { SKBR-3 and MCF-7 cell } \\
\text { lines }\end{array}$ & $\downarrow$ Cell growth & (153) \\
\hline \multirow[t]{2}{*}{39} & \multirow[t]{2}{*}{$\begin{array}{l}\text { Effect of } \\
\text { Components }\end{array}$} & & $\begin{array}{l}{[\mathrm{Cd} 2(\mathrm{Dic}) 41.5(\mathrm{MeOH}) 2(\mathrm{H} 2 \mathrm{O})] \mathrm{n}(\mathrm{Dic}=} \\
\text { diclofenac sodium })\end{array}$ & $\begin{array}{l}\text { MCF7,T24,L-929 and A- } \\
549 \text { cell lines }\end{array}$ & $\downarrow$ Cell proliferation & \multirow[t]{2}{*}{ (154) } \\
\hline & & & $\begin{array}{l}{[\mathrm{Cd} 2(\mathrm{Dic}) 41.5(\mathrm{MeOH}) 2(\mathrm{H} 20)] \mathrm{n} \text { in comparison }} \\
\text { with Dic and Cd2 }\end{array}$ & MCF7,T24 cell lines & $\uparrow$ Cytotoxicity & \\
\hline \multirow[t]{2}{*}{40} & \multirow[t]{2}{*}{$\begin{array}{l}\text { Effect of } \\
\text { Components }\end{array}$} & & $\begin{array}{l}\text { Equol(metabolite of the soybean isoflavone } \\
\text { daidzein) }\end{array}$ & $\begin{array}{l}\text { MDA- } \\
\text { MB231(IC50:252 } \mu \mathrm{M}) \\
\text { and T47D(IC50 } 228 \mu \mathrm{M})\end{array}$ & $\downarrow$ Cell proliferation & \multirow[t]{2}{*}{ (155) } \\
\hline & & & & $\begin{array}{l}\text { MDA-MB-231(IC50 } \\
50 \mu \mathrm{M} \text { and T47D(IC50 } \\
50 \mu \mathrm{M})\end{array}$ & $\begin{array}{l}\uparrow \text { Radiation-induced } \\
\text { apoptosis }\end{array}$ & \\
\hline \multirow[t]{2}{*}{41} & \multirow[t]{2}{*}{$\begin{array}{l}\text { New } \\
\text { Technologies }\end{array}$} & & methotrexate-human serum albu- & \multirow{2}{*}{$\begin{array}{l}\text { Female Balb/c mice } \\
\text { bearing } 4 \mathrm{~T} 1 \text { cell line }\end{array}$} & \multirow[t]{2}{*}{$\uparrow$ Survival } & \multirow[t]{2}{*}{ (156) } \\
\hline & & & $\begin{array}{l}\text { min nanoparticles(MTX-HSA NPs) with } \\
\text { luteinizing-hormone releasing hormone(LHRH) }\end{array}$ & & & \\
\hline \multirow[t]{2}{*}{42} & \multirow[t]{2}{*}{ Biomarkers } & $\begin{array}{l}\text { MMP-3,MMP- } \\
9 \text { and TIMP-1 } \\
\text { cell lines }\end{array}$ & & $\begin{array}{l}\text { Female Balb/c mice } \\
\text { bearing } \\
\text { adenocarcinoma breast } \\
\text { tumor + Candida } \\
\text { Albicans, Female } \\
\text { BALB/c mice was } \\
\text { infected Candida } \\
\text { Albicans and Female } \\
\text { Balb/c mice bearing } \\
\text { adenocarcinoma breast } \\
\text { tumor }\end{array}$ & $\uparrow$ Secretion & \multirow[t]{2}{*}{$(157)$} \\
\hline & & MMP-2 & & $\begin{array}{l}\text { Female Balb/c mice } \\
\text { bearing } \\
\text { adenocarcinoma breast } \\
\text { tumor + Candida } \\
\text { Albicans and Female } \\
\text { BALB/c mice was } \\
\text { infected Candida } \\
\text { Albicans }\end{array}$ & $\downarrow$ Secretion & \\
\hline 43 & $\begin{array}{l}\text { Effect of } \\
\text { Components }\end{array}$ & $\begin{array}{l}\text { Extracellular } \\
\text { Signal- } \\
\text { Regulated } \\
\text { Kinases } 1 / 2 \\
\text { (ERK) and } \\
\text { phospho-ERK }\end{array}$ & DOX & $\begin{array}{l}\text { MDA-MB-231 (ER-) cell } \\
\text { line }\end{array}$ & $\downarrow$ Expression & (158) \\
\hline \multicolumn{7}{|c|}{ Web of Science, PubMed, Scopus, SID, IranMedex } \\
\hline \multicolumn{7}{|c|}{ Jan 2005-Oct2015 } \\
\hline \multicolumn{7}{|c|}{1986 English Citation(s) } \\
\hline 1345 & ersian Citation(s & & & & & \\
\hline
\end{tabular}




\begin{tabular}{|c|c|c|c|c|c|c|}
\hline No. & Type of Study & $\begin{array}{l}\text { Gene } \\
\text { /Protein/ Cell } \\
\text { Activity }\end{array}$ & Drug /Extract/ Component name & $\begin{array}{l}\text { Cell Line, Tissue, Animal } \\
\text { model name }\end{array}$ & Effect & Ref. \\
\hline & & $\begin{array}{l}\text { Extracellular } \\
\text { Signal- } \\
\text { Regulated } \\
\text { Kinases } 1 / 2 \\
\text { and phospho- } \\
\text { ERK }\end{array}$ & DOX & MCF-7 (ER+) cell line & $\uparrow$ Expression & \\
\hline & & $\begin{array}{l}\text { Extracellular } \\
\text { Signal- } \\
\text { Regulated } \\
\text { Kinases } 1 / 2 \\
\text { (ERK) and } \\
\text { phospho-ERK }\end{array}$ & DOCT & $\begin{array}{l}\text { MDA-MB-231 (ER-) cell } \\
\text { line }\end{array}$ & $\downarrow$ Expression & \\
\hline & & $\begin{array}{l}\text { Extracellular } \\
\text { Signal- } \\
\text { Regulated } \\
\text { Kinases } 1 / 2 \\
\text { (ERK) and } \\
\text { phospho-ERK }\end{array}$ & DOCT & MCF-7 (ER+) cell line & $\uparrow$ Expression & \\
\hline \multirow[t]{2}{*}{44} & \multirow{2}{*}{$\begin{array}{l}\text { Immunotherapy- } \\
\text { Immunology }\end{array}$} & \multirow[t]{2}{*}{ HER2 } & anti-HER2 mAbs 1T0, 2 A8 and both & \multirow[t]{2}{*}{ BT474 cell line } & $\downarrow$ Cell proliferation & \multirow[t]{2}{*}{ (38) } \\
\hline & & & trastuzumab, 1T0 and 2A8 & & $\begin{array}{l}\text { significant } \\
\text { synergistic } \downarrow \text { Cell } \\
\text { proliferation }\end{array}$ & \\
\hline \multirow[t]{4}{*}{45} & \multirow[t]{4}{*}{$\begin{array}{l}\text { Effect of } \\
\text { Components }\end{array}$} & & Proline-rich heptapeptide $11 a-b$ and $11 \mathrm{i}-\mathrm{j}$ & $\begin{array}{l}\text { HL60,MCF7 and A549 } \\
\text { cell lines }\end{array}$ & $\begin{array}{l}\text { little or no effect on } \\
\text { cell viability }\end{array}$ & \multirow[t]{4}{*}{$(159)$} \\
\hline & & & Proline-rich heptapeptide $11 \mathrm{e}$ & $\begin{array}{l}\text { A549 and MCF7 cell } \\
\text { lines }\end{array}$ & $\begin{array}{l}\text { little or no effect on } \\
\text { cell viability }\end{array}$ & \\
\hline & & & Proline-rich heptapeptide $11 \mathrm{~d}$ and $11 \mathrm{~h}$ & MCF7 cell line & $\begin{array}{l}60 \% \text { effect on cell } \\
\text { viability }\end{array}$ & \\
\hline & & & Proline-rich heptapeptide $11 \mathrm{c}$ and $11 \mathrm{~g}$ & MCF7 cell line & $\begin{array}{l}10 \% \text { effect on cell } \\
\text { viability }\end{array}$ & \\
\hline \multirow[t]{2}{*}{46} & \multirow[t]{2}{*}{$\begin{array}{l}\text { Effect of } \\
\text { Components }\end{array}$} & \multirow[t]{2}{*}{ EGFR } & ASOND-loaded chitosan particles & \multirow[t]{2}{*}{ T47D cell line } & $\begin{array}{l}\text { Downregulated } \\
\text { expression }\end{array}$ & \multirow[t]{2}{*}{$(160)$} \\
\hline & & & ASOND-loaded thiolated particles & & $\downarrow$ Expression & \\
\hline 47 & $\begin{array}{l}\text { Effect of } \\
\text { Components }\end{array}$ & & $\begin{array}{l}\text { 13-S-hydroxyoctadecadienoic acid (13(S)- } \\
\text { HODE) }\end{array}$ & $\begin{array}{l}\text { MCF7 and MDA-MB-231 } \\
\text { cell lines }\end{array}$ & $\begin{array}{l}\downarrow \text { Cell growth, induce } \\
\text { apoptosis }\end{array}$ & (161) \\
\hline 48 & $\begin{array}{l}\text { Effect of } \\
\text { Components }\end{array}$ & $\begin{array}{l}15- \\
\text { Lipoxygenase- } \\
1\end{array}$ & Trichostatin A (TSA) & $\begin{array}{l}\text { MCF7 and MDA-MB-231 } \\
\text { cell lines }\end{array}$ & $\begin{array}{l}\downarrow \text { Cell viability and } \\
\text { cell growth, induce } \\
\text { apoptosis }\end{array}$ & (162) \\
\hline \multirow[t]{3}{*}{49} & \multirow[t]{3}{*}{$\begin{array}{l}\text { Effect of } \\
\text { Components }\end{array}$} & & $\begin{array}{l}\text { Methanol extract of Salvia chloroleuca,n- } \\
\text { hexane and } \mathrm{CH} 2 \mathrm{Cl} 2\end{array}$ & \multirow[t]{3}{*}{ MCF-7 cell line } & $\downarrow$ Cell viability & \multirow[t]{3}{*}{$(163)$} \\
\hline & & & $\mathrm{CH} 2 \mathrm{Cl} 2$ & & Apoptosis & \\
\hline & & & $\begin{array}{l}\text { Total methanol extract of S. chloroleuca,n- } \\
\text { hexane,CH2Cl2EtOAc, n-BuOH, and H2O }\end{array}$ & & $\downarrow$ Cell growth & \\
\hline 50 & $\begin{array}{l}\text { Effect of } \\
\text { Components }\end{array}$ & miR-145 & Chitosan polyplex nanoparticles & MCF-7 cell line & $\downarrow$ Cell proliferation & (164) \\
\hline \multirow[t]{3}{*}{51} & \multirow[t]{3}{*}{$\begin{array}{l}\text { Effect of } \\
\text { Components }\end{array}$} & & $\begin{array}{l}\text { (pH-sensitive)MTO PEG-PMMI- CholC6 and } \\
\text { CHEMS-based bearing niosomes }\end{array}$ & $\begin{array}{l}\text { HUVEC,OVCAR-3 and } \\
\text { MCF-7 Cell lines }\end{array}$ & $\begin{array}{l}\uparrow \text { Antiproliferative } \\
\text { activity }\end{array}$ & \multirow[t]{3}{*}{ (165) } \\
\hline & & & $\begin{array}{l}\text { (pH-sensitive)MTO conventional, PEG-PMMI- } \\
\text { CholC6 and CHEMS-based bearing niosomes }\end{array}$ & $\begin{array}{l}\text { HUVEC,OVCAR-3 and } \\
\text { MCF-7 Cell lines }\end{array}$ & $\uparrow$ Cytotoxicity & \\
\hline & & & $\begin{array}{l}\text { (pH-sensitive)MTO conventional, PEG-PMMI- } \\
\text { CholC6 and CHEMS-based bearing niosomes }\end{array}$ & $\begin{array}{l}\text { OVCAR-3 and MCF-7 } \\
\text { Cell lines }\end{array}$ & $\downarrow$ Cell viability & \\
\hline \multirow[t]{2}{*}{52} & \multirow[t]{2}{*}{$\begin{array}{l}\text { Effect of } \\
\text { Components }\end{array}$} & & Valproic acid (VPA) & \multirow[t]{2}{*}{ MCF-7 cell line } & $\begin{array}{l}\downarrow \text { Cell viability, } \\
\text { Apoptosis }\end{array}$ & \multirow[t]{2}{*}{$(166)$} \\
\hline & & Telomerase & Valproic acid (VPA) & & $\downarrow$ Activity & \\
\hline \multicolumn{7}{|c|}{ Web of Science, PubMed, Scopus, SID, IranMedex } \\
\hline \multicolumn{7}{|c|}{ Jan 2005-Oct2015 } \\
\hline \multicolumn{7}{|c|}{1986 English Citation(s) } \\
\hline 1345 & ersian Citation(s) & & & & & \\
\hline
\end{tabular}




\begin{tabular}{|c|c|c|c|c|c|c|}
\hline No. & Type of Study & $\begin{array}{l}\text { Gene } \\
\text { /Protein/ Cell } \\
\text { Activity }\end{array}$ & Drug /Extract/ Component name & $\begin{array}{l}\text { Cell Line, Tissue, Animal } \\
\text { model name }\end{array}$ & Effect & Ref. \\
\hline & & $\mathrm{Bax} / \mathrm{Bcl}-2$ & Valproic acid (VPA) & & $\begin{array}{l}\uparrow B a x \text { and } \downarrow \text { Bcl-2 } \\
\text { expression and } \\
\uparrow B a x / B c l-2 \text { ratio }\end{array}$ & \\
\hline & & $\begin{array}{l}\text { Telomerase } \\
\text { activity \& in } \\
\text { Bax/Bcl-2 } \\
\text { ratio }\end{array}$ & & & $\begin{array}{l}\text { significant } \\
\text { correlation }\end{array}$ & \\
\hline \multirow[t]{2}{*}{53} & \multirow{2}{*}{$\begin{array}{l}\text { Effect of } \\
\text { Components }\end{array}$} & & Scrophularia oxysepala(n-hexane extract) & \multirow[t]{2}{*}{ MCF-7 cell line } & no cytotoxic effects & \multirow[t]{2}{*}{$(167)$} \\
\hline & & & $\begin{array}{l}\text { Scrophularia oxysepala(dichloromethae and } \\
\text { methanol extract) }\end{array}$ & & $\begin{array}{l}\downarrow \text { Cell growth, } \downarrow \\
\text { viability, apoptosis }\end{array}$ & \\
\hline 54 & $\begin{array}{l}\text { Effect of } \\
\text { Components }\end{array}$ & p53 & Boswellia Thurifera Gum Methanol Extract & MDA-MB-231 cell line & $\begin{array}{l}\uparrow \text { Expression, } \\
\text { cytotoxic effect }\end{array}$ & (168) \\
\hline 55 & $\begin{array}{l}\text { Effect of } \\
\text { Components }\end{array}$ & & docetaxel-coated Fe304 MNPs & 4 T1 cell line & $\begin{array}{l}\uparrow \text { Cell death than } \\
\text { docetaxel alone }\end{array}$ & (169) \\
\hline \multirow[t]{3}{*}{56} & \multirow[t]{3}{*}{$\begin{array}{l}\text { Effect of } \\
\text { Components }\end{array}$} & & $\begin{array}{l}\text { Lactobacillus plantarum enriched with } \\
\text { selenium nanoparticles(SeNPs) }\end{array}$ & $\begin{array}{l}\text { FemaleBALB/c mice } \\
\text { with } 4 \mathrm{~T} 1 \text { cell line }\end{array}$ & $\begin{array}{l}\downarrow \text { Growth rate of } \\
\text { tumors, } \downarrow \text { Rate of } \\
\text { death, } \uparrow \text { Survival }\end{array}$ & \multirow[t]{3}{*}{ (169) } \\
\hline & & $\begin{array}{l}\text { IFN-y, TNF-a } \\
\text { and IL-2 }\end{array}$ & $\begin{array}{l}\text { Lactobacillus plantarum enriched with } \\
\text { selenium nanoparticles(SeNPs) }\end{array}$ & $\begin{array}{l}\text { Female BALB/c mice } \\
\text { with } 4 T 1 \text { cell line }\end{array}$ & $\begin{array}{l}\uparrow \text { Production, } \uparrow \mathrm{NK} \\
\text { cells cytotoxicity }\end{array}$ & \\
\hline & & LDH & & & $\downarrow$ Production & \\
\hline \multirow[t]{3}{*}{57} & \multirow[t]{3}{*}{$\begin{array}{l}\text { Effect of } \\
\text { Components }\end{array}$} & & $\begin{array}{l}\text { Selenium nanoparticle(SeNPs)-enriched } \\
\text { Lactobacillus } \\
\text { brevis }\end{array}$ & $\begin{array}{l}\text { Female BALB/c mice } \\
\text { with } 4 \mathrm{~T} 1 \text { cell line }\end{array}$ & $\begin{array}{l}\downarrow \text { Growth rate of } \\
\text { tumors, } \downarrow \text { Rate of } \\
\text { death, } \uparrow \\
\text { Survival, } \uparrow \text { Tumor } \\
\text { necrosis, } \downarrow \text { Metastasis }\end{array}$ & \multirow[t]{3}{*}{$(170)$} \\
\hline & & $\begin{array}{l}\text { IFN-y and IL- } \\
17\end{array}$ & & & $\begin{array}{l}\uparrow \text { Production, } \uparrow N K \\
\text { cells cytotoxicity }\end{array}$ & \\
\hline & & LDH and ALP & & & $\downarrow$ Production & \\
\hline \multirow[t]{2}{*}{58} & \multirow[t]{2}{*}{$\begin{array}{l}\text { Effect of } \\
\text { Components }\end{array}$} & & Biogenic Selenium Nanoparticles & $\begin{array}{l}\text { Female BALB/c mice } \\
\text { with } 4 T 1 \text { cell line }\end{array}$ & $\begin{array}{l}\downarrow \text { Growth rate of } \\
\text { tumors, } \downarrow \text { Rate of } \\
\text { death, } \uparrow \text { Survival }\end{array}$ & \multirow[t]{2}{*}{ (171) } \\
\hline & & $\begin{array}{l}\text { IFN-y, IL-12, IL- } \\
2 \text {, and TNF-a }\end{array}$ & & & $\uparrow$ production & \\
\hline 59 & $\begin{array}{l}\text { Immunotherapy- } \\
\text { Immunology }\end{array}$ & & TGFaL3-SEB & $4 T 1$ cell line & $\uparrow$ Antitumor activities & (172) \\
\hline 60 & $\begin{array}{l}\text { Effect of } \\
\text { Components }\end{array}$ & & Curcumin-loaded NIPAAm-MAA & MCF-7 cell line & $\begin{array}{l}\text { More cytotoxic effect } \\
\text { and efficiently } \downarrow \text { cell } \\
\text { growth than } \\
\text { curcumin alone }\end{array}$ & (173) \\
\hline 61 & $\begin{array}{l}\text { Effect of } \\
\text { Components }\end{array}$ & $\begin{array}{l}\text { Autocrine hGH } \\
\text { (Human } \\
\text { growth } \\
\text { hormone) }\end{array}$ & Arsenic trioxide (ATO) & $\begin{array}{l}\text { MCF7-hGH than MCF-7 } \\
\text { cell line }\end{array}$ & $\begin{array}{l}\uparrow \text { Expression, } \downarrow \text { Cell } \\
\text { viability, } \downarrow \text { colony } \\
\text { formation, } \\
\uparrow \text { Apoptosis }\end{array}$ & (174) \\
\hline 62 & $\begin{array}{l}\text { Effect of } \\
\text { Components }\end{array}$ & & $\begin{array}{l}\text { Lactobacillus Rhamnosus, cisplatin, } \\
\text { Lactobacillus Rhamnosus + cisplatin }\end{array}$ & Female BALB/c Mice & $\begin{array}{l}\downarrow \text { Growth rate of } \\
\text { tumors }\end{array}$ & (175) \\
\hline \multirow[t]{2}{*}{63} & \multirow[t]{2}{*}{$\begin{array}{l}\text { Effect of } \\
\text { Components }\end{array}$} & IFN-y & aqueous extract of Carica papaya leaves & Female BALB/c Mice & $\begin{array}{l}\uparrow \text { Expression, } \\
\downarrow \text { Growth rate of } \\
\text { tumors }\end{array}$ & \multirow[t]{2}{*}{$(175)$} \\
\hline & & IL- 4 & & & $\downarrow$ Expression & \\
\hline 64 & $\begin{array}{l}\text { Effect of } \\
\text { Components }\end{array}$ & HER2 & Silybin & SKBR3 cell line & $\begin{array}{l}\downarrow \text { Cell growth, } \\
\downarrow \text { Expression }\end{array}$ & (176) \\
\hline
\end{tabular}

\begin{tabular}{|l|}
\hline Web of Science, PubMed, Scopus, SID, IranMedex \\
\hline Jan 2005 -Oct2015 \\
\hline 1986 English Citation(s) \\
\hline 1345 Persian Citation(s) \\
\hline
\end{tabular}




\begin{tabular}{|c|c|c|c|c|c|c|}
\hline No. & Type of Study & $\begin{array}{l}\text { Gene } \\
\text { /Protein/ Cell } \\
\text { Activity }\end{array}$ & Drug /Extract/ Component name & $\begin{array}{l}\text { Cell Line, Tissue, Animal } \\
\text { model name }\end{array}$ & Effect & Ref. \\
\hline 65 & $\begin{array}{l}\text { Effect of } \\
\text { Components }\end{array}$ & & $\begin{array}{l}\text { Neutra Charged liposomes-encapsulated } \\
\text { Doxorubicin }\end{array}$ & MDA-MB-231 cell line & $\begin{array}{l}\text { More cytotoxic effec } \\
\text { than Negative } \\
\text { Charged liposomes- } \\
\text { encapsulated } \\
\text { Doxorubicin and free } \\
\text { Doxorubicin }\end{array}$ & $(39)$ \\
\hline 66 & $\begin{array}{l}\text { Effect of } \\
\text { Components }\end{array}$ & & Artemisia absinthium L.(Grown at high height) & MCF7 cell line & $\begin{array}{l}\uparrow \text { Cytotoxicity than } \\
\text { others }\end{array}$ & $(177)$ \\
\hline 67 & $\begin{array}{l}\text { Effect of } \\
\text { Components }\end{array}$ & & Acetazolamide & T47-D cell line & $\begin{array}{l}\text { No effect on } \\
\text { apoptosis and cell } \\
\text { cycle arrest }\end{array}$ & $(178)$ \\
\hline \multirow[t]{2}{*}{68} & \multirow[t]{2}{*}{$\begin{array}{l}\text { Effect of } \\
\text { Components }\end{array}$} & & Methanolic extract of Avicennia marina & \multirow[t]{2}{*}{ MDA-MB231 cell line } & $\begin{array}{l}\downarrow \text { Cell growth and } \\
\text { induce apoptosis } \\
\text { more than other } \\
\text { extraction }\end{array}$ & \multirow[t]{2}{*}{ (179) } \\
\hline & & & Ethanolic extract of Avicennia marina & & $\begin{array}{l}\uparrow \text { Cytotoxicity more } \\
\text { than other extraction }\end{array}$ & \\
\hline 69 & $\begin{array}{l}\text { Effect of } \\
\text { Components }\end{array}$ & & Letrozole loaded lipid nanocapsules (LNCs) & MCF7 cell line & $\begin{array}{l}\downarrow \text { Cytotoxicity in } \\
\text { comparison with free } \\
\text { letrozole }\end{array}$ & $(180)$ \\
\hline 70 & $\begin{array}{l}\text { Effect of } \\
\text { Components }\end{array}$ & CD83 & Melphalan alkylating + TNF- $\mathrm{a}$ and MCM & MCF7 cell line & $\begin{array}{l}\uparrow \text { Expression, } \\
\text { \Phagocytosis, } \\
\text { polarized immune } \\
\text { responses to DC1 } \\
\text { phenotype triggering } \\
\text { TH1 responses }\end{array}$ & $(181)$ \\
\hline 71 & $\begin{array}{l}\text { Effect of } \\
\text { Components }\end{array}$ & & $\begin{array}{l}\text { Ethanolic Extract of ginger fresh extract } \\
\text { (Zingiber) }\end{array}$ & MCF7 cell line & $\begin{array}{l}\downarrow \text { Cell growth, } \\
\text { Cytotoxic effect, } \\
\text { induce apoptosis }\end{array}$ & $(182)$ \\
\hline 72 & $\begin{array}{l}\text { Effect of } \\
\text { Components }\end{array}$ & Telomerase & Curcuma longa $\mathrm{n}$-hexane extract & MCF7 cell line & $\begin{array}{l}\downarrow \text { Expression, } \downarrow \text { Cell } \\
\text { growth }\end{array}$ & $(183)$ \\
\hline 73 & $\begin{array}{l}\text { Effect of } \\
\text { Components }\end{array}$ & & Saffron & MCF7 cell line & $\begin{array}{l}\downarrow \text { Cell viability, induce } \\
\text { apoptosis }\end{array}$ & $(184)$ \\
\hline 74 & $\begin{array}{l}\text { Effect of } \\
\text { Components }\end{array}$ & & Lactobacillus Reuteri & Female BALB/c Mice & $\begin{array}{l}\downarrow \text { Growth rate of } \\
\text { tumors, } \uparrow \text { Weight, } \\
\uparrow \text { Survival, } \uparrow \text { Tumor } \\
\text { Cell death }\end{array}$ & $(185)$ \\
\hline \multirow[t]{2}{*}{75} & \multirow[t]{2}{*}{ Biomarkers } & $\begin{array}{l}\text { interlukin-6 } \\
\text { (IL-6) and } \\
\text { Vascular }\end{array}$ & $\begin{array}{l}\text { Rest-tumor-exercise(RTE) and Rest-tumor-rest } \\
\text { (RTR) }\end{array}$ & \multirow[t]{2}{*}{$\begin{array}{l}\text { Female BALB/c with } \\
\text { MC4L2 cell line }\end{array}$} & $\uparrow$ Expression & \multirow[t]{2}{*}{$(186)$} \\
\hline & & $\begin{array}{l}\text { endothelial } \\
\text { growth factor } \\
\text { (VEGF) }\end{array}$ & $\begin{array}{l}\text { Rest-tumor-rest (RTR) and Exercise-tumor-rest } \\
\text { (ETR) }\end{array}$ & & $\begin{array}{l}\uparrow \text { Growth rate of } \\
\text { tumors }\end{array}$ & \\
\hline 76 & Biomarkers & $\begin{array}{l}\text { 2H1-TP, KALA- } \\
\text { 2H1-TP and } \\
\text { KALA-2H1- } \\
\text { NLS-TP }\end{array}$ & histone $\mathrm{H} 1$-based recombinant fusion peptide & $\begin{array}{l}\text { ZR-75-1 cell line( } \mathrm{P} \\
\text { control) MDA-MB-231 } \\
\text { cell line( } \mathrm{N} \text { control) }\end{array}$ & $\begin{array}{l}\text { No significant } \\
\text { cytotoxicity effect } \\
\text { and cell viability }\end{array}$ & $(187)$ \\
\hline 77 & $\begin{array}{l}\text { Immunotherapy- } \\
\text { Immunology }\end{array}$ & INF-Y and IL-4 & Lip-DOPE-P5-MPL & $\begin{array}{l}\text { Female BALB/c mice } \\
\text { with TUBO cells }\end{array}$ & $\begin{array}{l}\text { No immunological } \\
\text { responses and } \\
\text { antitumor effect }\end{array}$ & $(188)$ \\
\hline 78 & $\begin{array}{l}\text { New } \\
\text { Technologies }\end{array}$ & MUC1 antigen & USPIO-C595 & $\begin{array}{l}\text { MCF-7, MDA-MB-231 } \\
\text { and LNCap cell lines, } \\
\text { BALB/c mice with } \\
\text { MUC1-positive breast } \\
\text { tumor }\end{array}$ & $\uparrow$ Uptake & $(189)$ \\
\hline 79 & $\begin{array}{l}\text { New } \\
\text { Technologies }\end{array}$ & & $\begin{array}{l}\text { 2-aryl-3-nitro-2H-chromenes 4a-u,2-aryl-3-nitro- } \\
\text { 2H-chromenes } 4 \mathrm{I}\end{array}$ & MCF-7 cell line & $\begin{array}{l}\uparrow \text { Activity }, \uparrow \uparrow \uparrow \text { Activity } \\
\text { compare with } \\
\text { Etoposide }\end{array}$ & $(190)$ \\
\hline \multicolumn{7}{|c|}{ Web of Science, PubMed, Scopus, SID, IranMedex } \\
\hline \multicolumn{7}{|c|}{ Jan 2005-Oct2015 } \\
\hline \multicolumn{7}{|c|}{1986 English Citation(s) } \\
\hline 1345 & ersian Citation(s) & & & & & \\
\hline
\end{tabular}




\begin{tabular}{|c|c|c|c|c|c|c|}
\hline No. & Type of Study & $\begin{array}{l}\text { Gene } \\
\text { /Protein/ Cell } \\
\text { Activity }\end{array}$ & Drug /Extract/ Component name & $\begin{array}{l}\text { Cell Line, Tissue, Animal } \\
\text { model name }\end{array}$ & Effect & Ref. \\
\hline & & & $\begin{array}{l}\text { 2-aryl-3-nitro-2H-chromenes } \\
\text { 4a,4b,4c,4d,4e,4f,4 g,4h,4j,4 k,4 I,4 m,4n,4o,4p,4r } \\
\text { and } 4 \mathrm{~s}\end{array}$ & T-47D cell line & $\begin{array}{l}\text { १Cytotoxicity } \\
\text { compare with } \\
\text { etoposide }\end{array}$ & \\
\hline & & & $\begin{array}{l}\text { 2-aryl-3-nitro-2H-chromenes } 4 \mathrm{a}-\mathrm{u} \text { instead of } \\
4 \mathrm{i}, 2 \text {-aryl-3-nitro-2H-chromenes } 4 \mathrm{~b}\end{array}$ & MDA-MB-231 cell line & $\begin{array}{l}\uparrow \text { Activity, } \uparrow \uparrow \text { Activity } \\
\text { compare with } \\
\text { Etoposide }\end{array}$ & \\
\hline & & & 2-aryl-3-nitro-2H-chromenes $4 \mathrm{~h}$ and $4 \mathrm{I}$ & MDA-MB-231 cell line & $\begin{array}{l}\uparrow \text { Caspase-3 activity, } \\
\downarrow \text { Cell viability and } \\
\text { cell growth, } \\
\uparrow \text { apoptosis }\end{array}$ & \\
\hline & & & 2-aryl-3-nitro-2H-chromenes $4 \mathrm{~h}$ and $4 \mathrm{I}$ & MCF-7 cell line & $\begin{array}{l}\downarrow \text { Cell viability and } \\
\text { cell growth, } \\
\uparrow \text { apoptosis }\end{array}$ & \\
\hline \multirow[t]{3}{*}{80} & \multirow[t]{3}{*}{$\begin{array}{l}\text { New } \\
\text { Technologies }\end{array}$} & \multirow[t]{3}{*}{ IL-2 } & pCDNA-2 hinge CAR-OX40 & $\begin{array}{l}\text { MCF-7 and NIH3T3 cell } \\
\text { line }\end{array}$ & $\uparrow$ Expression & \multirow[t]{3}{*}{ (191) } \\
\hline & & & $\begin{array}{l}\text { pCDNA-2 hinge CAR and pCDNA-2 hinge CAR- } \\
\text { OX40 }\end{array}$ & T-47D cell line & $\uparrow$ Expression & \\
\hline & & & pCDNA3.1/HYGRO(+) & A-431 cell line & $\uparrow$ Expression & \\
\hline \multirow[t]{3}{*}{81} & \multirow[t]{3}{*}{$\begin{array}{l}\text { Effect of } \\
\text { Components }\end{array}$} & & lactobacillus acidophilus ATCC4356 strain & Female BALB/c mice & $\begin{array}{l}\uparrow \text { proliferation of } \\
\text { immune cells, } \\
\uparrow \text { survival rate } \\
\text { compare with control } \\
\text { mice }\end{array}$ & \multirow[t]{3}{*}{$(192)$} \\
\hline & & IFny & & & $\uparrow$ Expression & \\
\hline & & IL4 & & & $\downarrow$ Expression & \\
\hline \multirow[t]{4}{*}{82} & \multirow[t]{4}{*}{$\begin{array}{l}\text { Immunotherapy- } \\
\text { Immunology }\end{array}$} & & gp96N-terminal/Her2/GFP & $\begin{array}{l}\text { Female BALB/c mice } \\
\text { with TUBO cells }\end{array}$ & $\begin{array}{l}\downarrow \text { therapeutic } \\
\text { potentials of Her } 2\end{array}$ & \multirow[t]{4}{*}{ (193) } \\
\hline & & & & & DNA vaccine & \\
\hline & & Ifny,IL4 & gp96N-terminal/Her2/GFP & $\begin{array}{l}\text { TUBO cell-raised tumor } \\
\text { extract }\end{array}$ & $\begin{array}{l}\uparrow \text { Proliferation } \\
\text { compare with pHer2- } \\
\text { or pCT/Her2- } \\
\text { vaccinated animals }\end{array}$ & \\
\hline & & CD4+/CD8+ & gp96N-terminal/Her2/GFP & $\begin{array}{l}\text { TUBO cell-raised tumor } \\
\text { extract }\end{array}$ & $\begin{array}{l}\uparrow \text { Expression in the } \\
\text { order of pNT/Her2 }> \\
\text { pCT/Her2 }>\text { pHer2 }\end{array}$ & \\
\hline \multirow[t]{5}{*}{82} & \multirow[t]{5}{*}{$\begin{array}{l}\text { New } \\
\text { Technologies }\end{array}$} & & GP96 + Her2/Her2 & \multirow[t]{5}{*}{$\begin{array}{l}\text { Female BALB/c mice } \\
\text { with TUBO cells }\end{array}$} & $\begin{array}{l}\text { better in part } \\
\text { I Growth rate of } \\
\text { tumors, better in part } \\
\text { II Growth rate of } \\
\text { tumors, }\end{array}$ & \multirow[t]{5}{*}{ (194) } \\
\hline & & $\begin{array}{l}\text { CD } 4+\mathrm{CD} 25+ \\
\text { Foxp3+ }\end{array}$ & pHer2 + pGP96-vaccinated animals & & $\downarrow$ Expression & \\
\hline & & Ifny,IL4 & pHer2 + pGP96 & & $\begin{array}{l}\uparrow \text { Induce response, } \\
\uparrow \text { proliferation, } \\
\uparrow \text { Expression }\end{array}$ & \\
\hline & & CD4+ & pHer2 + & & $\uparrow$ Expression & \\
\hline & & & $\begin{array}{l}\text { pGP96-vaccinated miceand pHer2-vaccinated } \\
\text { mice }\end{array}$ & & & \\
\hline \multirow[t]{3}{*}{84} & \multirow[t]{3}{*}{$\begin{array}{l}\text { Immunotherapy- } \\
\text { Immunology }\end{array}$} & $\mathrm{IL}-4$ & T7-phage nanoparticles & \multirow{3}{*}{$\begin{array}{l}\text { Female BALB/c mice }(\mathrm{H}- \\
\text { 2d haplotype) with } \\
\text { TUBO cells }\end{array}$} & $\begin{array}{l}\uparrow \text { Expression compare } \\
\text { with control }\end{array}$ & \multirow[t]{3}{*}{ (195) } \\
\hline & & $\begin{array}{l}\lg G \\
\text { antibodies }\end{array}$ & T7-p66 Chimeric Nanoparticles & & $\begin{array}{l}\uparrow \text { Expression against } \\
\text { T7 capsids in all T7 } \\
\text { nanoparticle- }\end{array}$ & \\
\hline & & & & & immunized mice & \\
\hline \multicolumn{7}{|c|}{ Web of Science, PubMed, Scopus, SID, IranMedex } \\
\hline \multicolumn{7}{|c|}{ Jan 2005-Oct2015 } \\
\hline \multicolumn{7}{|c|}{1986 English Citation(s) } \\
\hline 1345 & ersian Citation(s) & & & & & \\
\hline
\end{tabular}




\begin{tabular}{|c|c|c|c|c|c|c|}
\hline No. & Type of Study & $\begin{array}{l}\text { Gene } \\
\text { /Protein/ Cell } \\
\text { Activity }\end{array}$ & Drug /Extract/ Component name & $\begin{array}{l}\text { Cell Line, Tissue, Animal } \\
\text { model name }\end{array}$ & Effect & Ref. \\
\hline & & Ifny & T7-p66 Chimeric Nanoparticles & & $\uparrow$ Expression & \\
\hline \multirow[t]{2}{*}{85} & \multirow[t]{2}{*}{$\begin{array}{l}\text { New } \\
\text { Technologies }\end{array}$} & & $\begin{array}{l}\text { 2-amino-4-aryl-4H-benzo[h or f]chromene-3- } \\
\text { carbonitrile } 4 \mathrm{~h} \text { and } 4 \mathrm{e}\end{array}$ & BT20 cell line & $\downarrow$ Cell proliferation & $(196)$ \\
\hline & & Src kinase & $\begin{array}{l}\text { 2-amino-4-aryl-4H-benzo[h or f]chromene-3- } \\
\text { carbonitrile } 4 \mathrm{~d}, 4 \mathrm{i}, 4 \mathrm{~m} \text {, and } 4 \mathrm{n}\end{array}$ & BT20 cell line & $\uparrow$ Inhibitory activity & \\
\hline 86 & Biomarkers & $\begin{array}{l}\text { IGF-1, } \\
\text { HGF,VEGF and } \\
\text { IL-8 }\end{array}$ & & $\begin{array}{l}\text { ASCs (Adipose derived } \\
\text { stem cells) }\end{array}$ & $\uparrow$ Expression & (197) \\
\hline \multirow[t]{2}{*}{87} & \multirow[t]{2}{*}{ Biomarkers } & $\begin{array}{l}\text { IL-10 and } \\
\text { TGF-b1 }\end{array}$ & & $\begin{array}{l}\text { ASCs (Adipose derived } \\
\text { stem cells) }\end{array}$ & \multirow[t]{2}{*}{ Higher expressions } & \multirow[t]{2}{*}{$(198)$} \\
\hline & & $\begin{array}{l}\text { IL-4, TGF-b1, } \\
\text { IL-10, CCR4 } \\
\text { and CD } 25\end{array}$ & & $\begin{array}{l}\text { PBLs (peripheral blood } \\
\text { lymphocytes) }\end{array}$ & & \\
\hline \multirow[t]{2}{*}{88} & \multirow[t]{2}{*}{$\begin{array}{l}\text { Immunotherapy- } \\
\text { Immunology }\end{array}$} & & TSA-P1-24 and A-P1-15 & $\begin{array}{l}\text { BT-20, BT-474, MDA-MB- } \\
361, \text { MDA- }\end{array}$ & \multirow[t]{2}{*}{$\uparrow$ Immune response } & \multirow[t]{2}{*}{ (199) } \\
\hline & & & & $\begin{array}{l}\text { MB-453, MDA-MB-468, } \\
\text { MCF-7, T-47D, SK-BR-3, } \\
\text { and Mel III cell lines }\end{array}$ & & \\
\hline \multirow[t]{3}{*}{89} & \multirow{3}{*}{$\begin{array}{l}\text { Immunotherapy- } \\
\text { Immunology } \\
\text { (DNA VAccine) }\end{array}$} & \multirow{3}{*}{$\begin{array}{l}\text { Anti-HER2 } \\
\text { antibody }\end{array}$} & fECD DNA & Female BALB/c mice & \multirow{3}{*}{$\begin{array}{l}\text { Induce anti Her2 } \\
\text { antibody response }\end{array}$} & \multirow[t]{3}{*}{$(200)$} \\
\hline & & & HER2 DNA subdomains (DI, DII, DIII, and DIV) & & & \\
\hline & & & & BT474 cell line & & \\
\hline \multirow[t]{3}{*}{90} & \multirow[t]{3}{*}{$\begin{array}{l}\text { Immunotherapy- } \\
\text { Immunology }\end{array}$} & & Tumoral ASCs & T cells & $\begin{array}{l}\uparrow \mathrm{CD} 4+\mathrm{CD} 25+ \\
\text { CD127LowFoxp3 + } \\
\text { and CD4 + CD25- } \\
\text { CD127LowFoxp3 + } \\
\text { Treg subsets }\end{array}$ & \multirow[t]{3}{*}{$(201)$} \\
\hline & & IL-4 and IL-10 & & & $\uparrow$ Expression & \\
\hline & & IFN-y & & & $\downarrow$ Expression & \\
\hline \multirow[t]{2}{*}{91} & \multirow[t]{2}{*}{$\begin{array}{l}\text { Immunotherapy- } \\
\text { Immunology }\end{array}$} & & Radiation & & $\begin{array}{l}\text { Higher chromatid } \\
\text { radiosensitivity }\end{array}$ & \multirow[t]{2}{*}{$(202)$} \\
\hline & & & Radiation & lymphocytes & $\begin{array}{l}\text { Higher background } \\
\text { SCE }\end{array}$ & \\
\hline \multirow[t]{2}{*}{92} & \multirow[t]{2}{*}{ Radiosensitivity } & & Radiation & leukocytes & $\begin{array}{l}\text { higher apoptosis } \\
\text { induction, }\end{array}$ & \multirow[t]{2}{*}{ (203) } \\
\hline & & & & & DNA damage & \\
\hline 93 & $\begin{array}{l}\text { Effect of } \\
\text { Components }\end{array}$ & $\begin{array}{l}\text { Bcl-2, } \\
\text { procaspase3 } \\
\text { and } \\
\text { procaspase9 }\end{array}$ & Econazole Nitrate & MCF-7 cell line & $\downarrow$ Expression & (204) \\
\hline \multirow[t]{4}{*}{94} & \multirow[t]{4}{*}{$\begin{array}{l}\text { Effect of } \\
\text { Components }\end{array}$} & & menadione & $\begin{array}{l}\text { trastuzumab-sensitive } \\
\text { SKBR3 cells }\end{array}$ & $\begin{array}{l}\text { †level of ROS, } \downarrow \text { level } \\
\text { of GSH }\end{array}$ & \multirow[t]{4}{*}{ (205) } \\
\hline & & & menadione + trastuzumab & $\begin{array}{l}\text { trastuzumab-sensitive } \\
\text { SKBR3 cells }\end{array}$ & $\begin{array}{l}\text { no effect on ROS, } \downarrow \\
\text { level of GSH }\end{array}$ & \\
\hline & & & menadione & $\begin{array}{l}\text { trastuzumab-resistant } \\
\text { SKBR3 cells }\end{array}$ & $\begin{array}{l}\downarrow \text { level of ROS and } \\
\text { GSH }\end{array}$ & \\
\hline & & & menadione + trastuzumab & $\begin{array}{l}\text { trastuzumab-resistant } \\
\text { SKBR3 cells }\end{array}$ & $\begin{array}{l}\text { no effect on ROS, } \downarrow \\
\text { level of GSH }\end{array}$ & \\
\hline 95 & $\begin{array}{l}\text { Immunotherapy- } \\
\text { Immunology }\end{array}$ & & & & $\begin{array}{l}\text { Higher CD } 8+T \text { cells } \\
\text { frequency }\end{array}$ & (206) \\
\hline \multicolumn{7}{|c|}{ Web of Science, PubMed, Scopus, SID, IranMedex } \\
\hline \multicolumn{7}{|c|}{ Jan 2005-Oct2015 } \\
\hline \multicolumn{7}{|c|}{1986 English Citation(s) } \\
\hline 1345 & ersian Citation(s) & & & & & \\
\hline
\end{tabular}




\begin{tabular}{|c|c|c|c|c|c|c|}
\hline \multirow[t]{4}{*}{ No. } & \multirow[t]{4}{*}{ Type of Study } & \multirow[t]{2}{*}{$\begin{array}{l}\text { Gene } \\
\text { /Protein/ Cell } \\
\text { Activity }\end{array}$} & \multirow[t]{4}{*}{ Drug / Extract/ Component name } & \multirow[t]{2}{*}{$\begin{array}{l}\text { Cell Line, Tissue, Animal } \\
\text { model name }\end{array}$} & \multirow{2}{*}{$\begin{array}{l}\text { Effect } \\
\text { Lower frequency of } \\
\text { CD4 + in macro- } \\
\text { metastatic dLN than } \\
\text { micro-metastatic dLN }\end{array}$} & \multirow[t]{2}{*}{ Ref. } \\
\hline & & & & & & \\
\hline & & granzyme B & & micro-metastatic dLN & Higher expression & \\
\hline & & CXCL10 & & & No difference & \\
\hline \multirow[t]{2}{*}{96} & \multirow{2}{*}{$\begin{array}{l}\text { New } \\
\text { Technologies }\end{array}$} & Dopamine & \multirow[t]{2}{*}{ Bromocriptine } & \multirow[t]{2}{*}{ MCF-7 CELLS } & \multirow[t]{2}{*}{$\uparrow$ Apoptosis } & \multirow[t]{2}{*}{$(207)$} \\
\hline & & Receptor D2 & & & & \\
\hline 97 & $\begin{array}{l}\text { Effect of } \\
\text { Components }\end{array}$ & $\begin{array}{l}\text { Adenosine } \\
\text { Receptors }\end{array}$ & Adenosine & $\begin{array}{l}\text { MDA-MB468 and MCF-7 } \\
\text { cells }\end{array}$ & $\uparrow$ Cell growth & (208) \\
\hline \multirow[t]{2}{*}{98} & \multirow[t]{2}{*}{$\begin{array}{l}\text { Effect of } \\
\text { Components }\end{array}$} & \multirow[t]{2}{*}{ cell growth } & \multirow[t]{2}{*}{ Zingiber } & \multirow[t]{2}{*}{ MCF-7 and L929 cells } & $\begin{array}{l}\text { Cytotoxic effects on } \\
\text { tumor cells, }\end{array}$ & \multirow[t]{2}{*}{ (209) } \\
\hline & & & & & $\begin{array}{l}\text { Negative cytotoxic } \\
\text { effect on normal } \\
\text { cells }\end{array}$ & \\
\hline 99 & Biomarkers & mir145 & mir145 vector & MCF10A/MCF7 & $\begin{array}{l}\uparrow \text { expression levels of } \\
\text { miR-145 in MCF10A }\end{array}$ & (210) \\
\hline \multirow[t]{2}{*}{100} & \multirow[t]{2}{*}{$\begin{array}{l}\text { Effect of } \\
\text { Components }\end{array}$} & $\begin{array}{l}\text { RARB, } \\
\text { BRCA1, }\end{array}$ & \multirow[t]{2}{*}{ folate and other one-carbon related nutrients } & \multirow[t]{2}{*}{$\begin{array}{l}149 \text { participants with } \\
\text { primary breast cancer }\end{array}$} & $\begin{array}{l}\uparrow \text { Frequency of } \\
\text { tumors with } \\
\text { methylation status at } \\
\text { RARB and }\end{array}$ & \multirow[t]{2}{*}{$(211)$} \\
\hline & & RASSF1A & & & BRCA1 genes. & \\
\hline 101 & $\begin{array}{l}\text { Effect of } \\
\text { Components }\end{array}$ & $\begin{array}{l}\text { Telomerase } \\
\text { Activity }\end{array}$ & Zinc, Selenium and Copper & $\begin{array}{l}\text { T47D cells and } 56 \\
\text { breast cancer patients }\end{array}$ & $\begin{array}{l}\text { Paradoxical } \\
\text { relationship between } \\
\text { trace elements levels } \\
\text { with telomerase } \\
\text { activity in tumor } \\
\text { tissue }\end{array}$ & (212) \\
\hline 102 & $\begin{array}{l}\text { Effect of } \\
\text { Components }\end{array}$ & Cell Growth & LACTOBACILLUS RHAMNOSUS & INBRED BALB/C MICE & $\begin{array}{l}\uparrow \text { Immune system } \\
\text { responses against } \\
\text { tumor }\end{array}$ & (213) \\
\hline 103 & $\begin{array}{l}\text { Effect of } \\
\text { Components }\end{array}$ & cell growth & Newcastle Disease Virus & MCF-7 cell line & $\begin{array}{l}\text { oncolytic effect of } \\
\text { NDV-AF2240 }\end{array}$ & (214) \\
\hline & & & & & $\begin{array}{l}\text { against the MCF- } \\
7 \text { cell line }\end{array}$ & \\
\hline 104 & $\begin{array}{l}\text { Effect of } \\
\text { Components }\end{array}$ & $\begin{array}{l}\text { Tumor Mass } \\
\text { Status, }\end{array}$ & Candida Albicans Infections (Candidiasis) & Balb/C Mice & $\begin{array}{l}\text { immunosuppressive } \\
\text { effects of candida } \\
\text { albicans on }\end{array}$ & (215) \\
\hline & & $\begin{array}{l}\text { intra Tumor } \\
\text { CD } 4 / C D 8 \\
\text { ratio of the } \\
\text { mammary } \\
\text { tumor }\end{array}$ & & & $\begin{array}{l}\text { proliferation of } \\
\text { lymphocytes }\end{array}$ & \\
\hline \multicolumn{7}{|c|}{ Web of Science, PubMed, Scopus, SID, IranMedex } \\
\hline \multicolumn{7}{|c|}{ Jan $2005-0$ ct2015 } \\
\hline \multicolumn{7}{|c|}{1986 English Citation(s) } \\
\hline \multicolumn{4}{|c|}{1345 Persian Citation(s) } & & & \\
\hline
\end{tabular}

\section{Diagnosis}

The fourth group included 9 studies with applications in breast cancer diagnosis. The majority of these studies compared various molecular methods such as differential PCR (216), multiplex PCR (217), Real-Time RT-PCR (218), quantitative reverse transcription-PCR (qRT-PCR) and multiplex ligation-dependent probe amplification (MLPA) (219) to immunohistochemistry. Kadivar et al. evaluated inter- and intraobserver reproducibility of assessment of HER2/neu immunostaining in invasive breast cancer (220). One of the studies introduced a developed label-free electrochemical miRNA biosensor based on employing methylene blue (MB) which confirmed by electrochemical impedance spectroscopy (EIS) and cyclic voltammetry (CV) methods (221). Other study developed a High-Performance Liquid Chromatography (HPLC) method for assessment of ErbB1 and ErbB2 genes amplification (222). Salimi et al. evaluate the gene amplification using dual-colour primed in situ labelling (PRINS) in comparison with fluorescence in situ hybridization (FISH) (223). Conjugation of monoclonal antibodies to SPIO informed as a useful method for the detection of tumor cells in the other study (224). 
The fifth group comprised 18 studies that could not be assigned to any of the abovementioned groups. They examined various issues including functional mechanisms of genes (225-231) animal models of the disease (232-235), familial breast cancer assessment (236-238), tumor environment simulation (239) and informatics studies $(240,241)$. One study optimised a method to prepare liposomes containing HER2/Neu-derived peptide as a vaccine delivery system for breast cancer (242).

\section{Ethical considerations}

Out of the 240 selected studies, 174 studies were conducted on human or animal samples. However, only $53.45 \%$ of these papers ( $n=53$ ) had ethical approval, and the rest did not address ethical issues (the other 71 studies did not consider ethical issues, either).

\section{Discussion}

Cellular and molecular studies conducted on breast cancer in Iran were divided into five groups: I) focusing on breast cancer susceptibility genes, II) genes affecting prognosis and survival, III) genes affecting therapeutic effects of different compounds on different grades of breast cancer cell lines, IV) studying about genes affecting breast cancer diagnosis, and $V$ ) studies which are focus on functional mechanisms of genes and establishment of animal models of breast cancer, respectively.

Studies in the first group investigated either germline or somatic mutations. Most of the researches were about BRCA1/2 gene. Most of the investigations on other susceptible genes did not consider family history. The critical problem in these studies was patient sampling difficulties and collecting clinical data and follow up variables. It seems that further studies on family pedigrees and germline mutations are required to confirm the role of mutations in susceptibility to cancer. Moreover, establishment and strengthening the cancer biobanks are very important which has been neglected these years (243) but, it is growing today.

In spite of increasing attention to the regulatory role of miRNAs, few of the reviewed studies focused on this subject. Most of them have shown the gene expression alteration in breast cancer. Further studies on large sample sizes in different populations would, hence, help clarify the relationship between miRNAs and various stages of cancer pathogenesis. Moreover investigating their targeting potency is recommended.

Numerous studies in the world have examined the effects of epigenetic changes on cancer. However, the number of such studies is very limited in Iran. Among all of the studied HIC 1 promoter hypermethylation was correlated with nodal involvement and tumor size. Since most epigenetic changes occur due to environmental and non-genetic factors $(22,67,164)$, studying the subject in sporadic patients can help clarify the role of the environment in the incidence of cancer. Moreover, these changes may affect the invasiveness of cancer or its response to medications $(244,245)$.

Hence, it is essential to conduct further studies to clarify susceptibility genes and their relationship with prognosis. Such studies will lead to the discovery of new genes or gene panels and facilitate decision-making during the treatment of patients with breast cancer. Conducting these studies in populations from different geographical locations is highly essential. However, most studies in Iran have been sporadic and with limited sample sizes. The majority of these studies have not assessed the patient survival rate or different subgroups of breast cancer separately. Performing reliable studies in this field would require access to not only the patients' clinical data but also biological banks and systems for regular collection and storage of biological samples. Limited reports of such banks are available in the country (e.g. BCRC-BB)(243). Moreover, since limited research resources are available, more extensive studies cannot be easily performed.

Another problem is that the majority of studies are researcher-oriented. Determining research priorities in specific fields by relevant institutions, e.g. the Ministry of Health or various universities, and aggregating and integrating the results of multi-center studies would probably yield stronger and more valid results. However, sporadic studies in single centers will not help the expansion of the boundaries of knowledge.

The majority of studies on the effects of herbal and medicinal compounds were at cell level or on mice. Considering the high therapeutic potentials of these compounds, the great interest of pharmaceutical companies in the screening and discovery of new medications based on the geographical area, vegetation cover, and microorganism populations in Iran, more serious studies in this field may be essential.

This review also assessed the ethical considerations in the selected articles. The absence of ethical approval, despite its necessity, indicates two points. Firstly, ethical approvals were not mandatory for biological studies before 2015 in Iran, and many researchers did not consider it as an essential issue in non-clinical studies. Now, the Ministry of Health has obliged researchers to obtain approval from an ethics committee. Secondly, and more importantly, it is evident that journals publishing such papers had no strict rules about the absence of ethical approval. In these cases, most of the researcher might have had ethical approval but did not provide the data due to journal policies. Considering the current policies in ethical aspects of researches in Iran, It is expected that this issue is modified in future studies.

\section{Conclusion}

Molecular Studies conducted in Iran between 2005-2015 evaluated breast cancer susceptibility genes, Prognosis, survival and clinicopathologic features of the patients, compounds with therapeutic properties, diagnosis and other issues. The majority of these studies were conducted sporadically and with small sample sizes. More qualified multi-center studies would require the development of biological banks and providing data from breast cancer patients with different characteristics. Moreover, considering the limitations of research funding and the importance of increasing knowledge about Iranian population Genetics, It seems that financial support by health system providers in this field is necessary.

\section{Abbreviations}


SID: Scientific Information Database

BRCA1/2: BReast CAncer genes 1 and 2

MeSH: Medical Subject Headings

NA: Not Assigned

CAT: CATalase

mRNA: Messenger RNA

miRNA: microRNA

NK: Natural Killer

MTT: [3-(4,5-Dimethylthiazol-2-yl)-2,5-Diphenyltetrazolium Bromide]

FFPE: Formalin-Fixed Paraffin-Embedded

PCR: Polymerase Chain Reaction

qRT-PCR: quantitative Reverse Transcription-PCR

MLPA: Multiplex Ligation-dependent Probe Amplification

MB: Methylene Blue

EIS: Electrochemical Impedance Spectroscopy

CV: Cyclic Voltammetry

HPLC: High-Performance Liquid Chromatography

PRINS: Primed In Situ Labeling

FISH: Fluorescence In Situ Hybridization

SPIO: Super Paramagnetic Iron Oxide

HIC1: Hypermethylated In Cancer 1

APOBEC3: Apolipoprotein B mRNA-Editing enzyme, Catalytic polypeptide-like 3

CCR5: C-C Chemokine Receptor type 5

CYP1A1: Human cytochrome P450 1A1

CYP2D6: Human Cytochrome P450 2D6

EGFR: Epidermal Growth Factor Receptor

ESR1: Estrogen Receptor 1

FGFR2: Fibroblast Growth Factor Receptor 2

GATA3: GATA Binding Protein 3

GSTM1: Glutathione S-Transferase Mu 1

GSTP1: Glutathione S-Transferase Pi gene

GSTT1: Glutathione S-Transferase (GST) Theta 1

GSTZ1: Glutathione S-Transferase Zeta 1

HLA: Human Leukocyte Antigen

IGF1: Insulin-like Growth Factor 1

IL: Interleukin 
MDR1: Multidrug Resistance Protein 1

SDF-1: Stromal cell-Derived Factor 1

TGF- $\beta 1$ : Transforming growth factor beta 1

VDR: Vitamin D Receptor

WRAP53: WD Repeat Containing Antisense To TP53

XRCC: X-ray Repair Cross-Complementing

DBC2: Deleted in Breast Cancer

PTEN: Phosphatase and Tensin homologue

MMP-9: Matrix MetalloPeptidase 9

MDM2: Murine Double Minute 2

\section{Declarations}

\section{Ethics approval and consent to participate}

This article does not contain any studies with human participants or animals performed by any of the authors. This research has been approved in Breast Cancer Research Center Ethical Committee with ethical code number "IR.ACECR.IBCRC.REC.1394.54"

\section{Consent for publication}

Not applicable.

\section{Availability of data and materials}

Not applicable.

\section{Competing interests}

The authors declare that they have no conflict of interest.

\section{Funding}

This study was a part of a comprehensive project to systematically review the different aspects of breast cancer in Iran. A grant from Roche Company funded the leading research.

\section{Authors' contributions}

RE managed the group and was responsible for the literature search, manuscript categorization, data extraction, writing manuscript. SHD and ZES participated in the literature search, data extraction, and preparation of tables and rechecking the data. TO was responsible for data extraction and rechecking the data. SH and $\mathrm{KM}$ managed the team in developing the idea in all steps of research including search, data extraction, preparing tables, writing the manuscript. All authors have participated in providing the first draft of the manuscript and they have approved the final version.

\section{Acknowledgements}

The researchers at the Breast Cancer Research Center appreciate the financial support of Roche Company for the development of this valuable breast cancer road map which facilitates future researches in Iran.

\section{References}

1. Bogdanova N, Helbig S, Dork T. Hereditary breast cancer: ever more pieces to the polygenic puzzle. Hereditary cancer in clinical practice. $2013 ; 11(1): 12$.

2. Harirchi I, Karbakhsh M, Kashefi A, Momtahen AJ. Breast cancer in Iran: results of a multi-center study. Asian Pacific journal of cancer prevention : APJCP. 2004;5(1):24-7.

3. Marotti JD, Schnitt SJ. Genotype-Phenotype Correlations in Breast Cancer. Surgical pathology clinics. 2018;11(1):199-211.

4. Wittersheim M, Buttner R, Markiefka B. Genotype/Phenotype correlations in patients with hereditary breast cancer. Breast care (Basel, Switzerland). 2015;10(1):22-6.

5. Shareef M, Ashraf MA, Sarfraz M. Natural cures for breast cancer treatment. Saudi Pharmaceutical Journal : SPJ. 2016;24(3):233-40.

6. Jamali M, Ebrahimi MA, Karimipour M, Shams-Ghahfarokhi M, Dinparast-Djadid N, Kalantari S, et al. An insight into the distribution, genetic diversity, and mycotoxin production of Aspergillus section Flavi in soils of pistachio orchards. Folia Microbiol (Praha). 2012;57(1):27-36. 
7. Khosravi N, Nazeri N, Farajivafa V, Olfatbakhsh A, Atashi A, Koosha M, et al. Supportive Care of Breast Cancer Patients in Iran: A Systematic Review. Int J Cancer Manag 2019;12(4):e83255.

8. Saadat M, Mousavi-Kazerooni F, Fallahzadeh-Abarghooei L. Distribution of genetic polymorphism of CAT C-262T in three Iranian populations. Turkish Journal of Biochemistry-Turk Biyokimya Dergisi. 2015;40(5):386-9.

9. Rostamizadeh L, Fakhrjou A, Montazeri V, Estiar MA, Naghavi-Behzad M, Hosseini S, et al. Bcl-2 gene expression in human breast cancers in iran. Asian Pacific journal of cancer prevention : APJCP. 2013;14(7):4209-14.

10. Shargh SA, Sakizli M, Khalaj V, Movafagh A, Yazdi H, Hagigatjou E, et al. Downregulation of E-cadherin expression in breast cancer by promoter hypermethylation and its relation with progression and prognosis of tumor. Medical oncology (Northwood, London, England). 2014;31(11):250.

11. Tabarestani S, Ghaderian SM, Rezvani H, Mirfakhraie R, Ebrahimi A, Attarian $\mathrm{H}$, et al. Prognostic and predictive value of copy number alterations in invasive breast cancer as determined by multiplex ligation-dependent probe amplification. Cellular oncology (Dordrecht). 2014;37(2):107-18.

12. Taghizadeh-Kermani A, Jafarian AH, Ashabyamin R, Seilanian-Toosi M, Pourali L, Asadi M, et al. The Stromal Overexpression of CD10 in Invasive Breast Cancer and its Association with Clincophathologic Factors. Iranian journal of cancer prevention. 2014;7(1):17-21.

13. Davarnia B, Mehdipour P, Arei M, Hosseini-Asl SS. The Association between BRCA1 Expression and Breast Cancer Tumorogenesis. Journal of Ardabil University of Medical Sciences. 2012;12(2):132-9.

14. Karimi Kivi A, Madjd Z, Hashemi F, Molanae S. Expression of BRCA1 protein in invasive and in situ carcinomas and its relation with marker of breast cancer stem cells (CD44) and prognostic factors in breast cancer patients*. Razi Journal of Medical Sciences. 2011;17(80):16-25.

15. Rahmati Yamchi M, Zarghami N, Rahbani Noubar M, Najafipour R, Mobasser M. Correlation between telomerase gene expression and different stages of breast cancer and obesity. The Journal of Qazvin University of Medical Sciences. 2012;16(2):35-43.

16. Fakheri T, Najafi B, Fadakar Soogheh G. Correlation Of P53 Protein Expression with Clinicopathologic Parameters and Hormonal Receptor Status in Breast Cancer Patients. Journal of Guilan University of Medical Sciences. 2006;15(58):1-6.

17. Zarghami N, Mohajri A, Fakhrjoo A, Montazeri A, Asadi J. Study of Prostate Specific Antigen Gene Expression and Telomerase in Breast Cancer Patients: Relationship to Steroid Hormone Receptors. Avicenna Journal of Clinical Medicine. 2007;14(3):10-8.

18. ASHOURZADEH S. PM, RASHIDI I.,NATEGHI J. A SURVEY OF RELATION TO NUCLEAR AND CYTOPLASMIC HSP70 AND P53 EXPRESSION IN BREAST CANCER. JUNDISHAPUR SCIENTIFIC MEDICAL JOURNAL. 2009;8(3):10.

19. M Moradi-Marjaneh FH-S, SAA Shamsian, I Eftekhar-Zadeh Mashhadi, MR Hedayati-Moghadam. Correlation of HER2/neu Over Expression, p53 Protein Accumulation and Steroid Receptor Status with Tumor Characteristics: An Iranian Study of Breast Cancer Patients Iranian J Publ Health. 2008;37(3):10.

20. Entezami K, Shah Ghasempour S, Rakhshan M, Nikrah E. Expression of MHC Class I and ICAM-I Association between Breast Cancer and Hyperplasia Biopsy Specimen in Women Aged between 35-65 Years by Indirect Immunofluorescence. Razi Journal of Medical Sciences. 2005;12(48):27-34.

21. Madjd Z, Akbari ME, Zarnani AH, Khayamzadeh M, Kalantari E, Mojtabavi N. Expression of EMSY, a Novel BRCA2-link Protein, is Associated with Lymph Node Metastasis and Increased Tumor Size in Breast Carcinomas. Asian Pacific Journal of Cancer Prevention. 2014;15(4):1783-9.

22. Savad S, Mehdipour P, Miryounesi M, Shirkoohi R, Fereidooni F, Mansouri F, et al. Expression analysis of MiR-21, MiR-205, and MiR-342 in breast cancer in Iran. Asian Pacific journal of cancer prevention : APJCP. 2012;13(3):873-7.

23. Ataee Kachoui MEKHKMK. Role of Chromosome 17 Aneusomy as a Prognostic Parameter in Some Iranian Women with Sporadic Breast Cancer Using Interphase FISH Technique. IRANIAN JOURNAL of PATHOLOGY. 2010;5(2):7.

24. Mohammad Reza Jalali Nadoushan , Ali Davati, Shahab Bagherzadeh Shahidi Expression of MDM2 gene in primary breast cancer and it's relationship with prognostic factors. Journal of Gorgan University of Medical Sciences. 2008;10(2):27-31.

25. Rasti M, Tavasoli P, Monabati A, Entezam M. Association between HIC1 and RASSF1A promoter hypermethylation with MTHFD1 G1958A polymorphism and clinicopathological features of breast cancer in Iranian patients. Iranian biomedical journal. 2009;13(4):199-206.

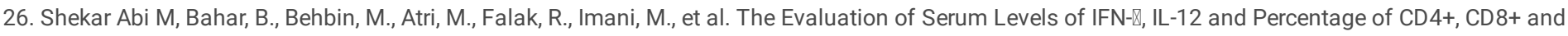
NK Cells in Peripheral Blood of Metastatic, Nonmetastatic Breast Cancer Patients and Normal Individuals. Razi Journal of Medical Sciences. 2008;14(57):113-20.

27. motovali-bashi M, Hojati Z, Sadeghi M. Investigation of gelatinase- B enzyme role in invasion and metastasis of breast cancer. Pejouhesh dar Pezeshki (Research in Medicine). 2008;32(2):89-93.

28. Sadeghi M, Hemmati S. Measurement of MMP-9 Expression Level for Treatment Assessment in Breast Cancer Patients. Knowledge \& Healt. 2008;3(4):204.

29. Hajihosseini S, Motavali-Bashi M, Hojjati-Najafabadi Z. 5A allel in matrix metalloproteinase-3 promoter and high risk of breast cancer metastasis Iranian Quarterly Journal of Breast Diseases. 2008;1(2):44-4-.

30. Sadeghi M, Hemmati S. Increasing in activity and plasma concentration of matrix metalloproteinase-9 in metastatic breast cancer patientsand its relation with this gene promoter T allele. Journal of Mazandaran University of Medical Sciences. 2009;19(71):44-51.

31. Taheri M, Mahjoubi F. MRP1 but not MDR1 is associated with response to neoadjuvant chemotherapy in breast cancer patients. Disease markers. 2013;34(6):387-93.

32. Abdolmohammadi MH, Fouladdel SH, Shafiee A, Amin GH, Ghaffari SM, Azizi E. Anticancer effects and cell cycle analysis on human breast cancer T47D cells treated with extracts of Astrodaucus persicus (Boiss.) Drude in comparison to doxorubicin. Daru-Journal of Pharmaceutical Sciences. 2008;16(2):112-8.

33. Oraki Kohshour M, Mirzaie S, Zeinali M, Amin M, Said Hakhamaneshi M, Jalili A, et al. Ablation of breast cancer cells using trastuzumab-functionalized multi-walled carbon nanotubes and trastuzumab-diphtheria toxin conjugate. Chemical biology \& drug design. 2014;83(3):259-65.

Page 23/31 
34. Rasaneh S, Rajabi H, Babaei MH, Daha FJ, Salouti M. Radiolabeling of trastuzumab with 177Lu via DOTA, a new radiopharmaceutical for radioimmunotherapy of breast cancer. Nuclear medicine and biology. 2009;36(4):363-9.

35. Rasaneh S, Rajabi H, Hossein Babaei M, Johari Daha F. Toxicity of trastuzumab labeled 177Lu on MCF7 and SKBr3 cell lines. Applied radiation and isotopes : including data, instrumentation and methods for use in agriculture, industry and medicine. 2010;68(10):1964-6.

36. Rastegar H, Ahmadi Ashtiani H, Anjarani S, Bokaee S, Khaki A, Javadi L. The role of milk thistle extract in breast carcinoma cell line (MCF-7) apoptosis with doxorubicin. Acta medica Iranica. 2013;51(9):591-8.

37. Rezaei PF, Fouladdel S, Cristofanon S, Ghaffari SM, Amin GR, Azizi E. Comparative cellular and molecular analysis of cytotoxicity and apoptosis induction by doxorubicin and Baneh in human breast cancer T47D cells. Cytotechnology. 2011;63(5):503-12.

38. Tahmasebi F, Kazemi T, Amiri MM, Khoshnoodi J, Mahmoudian J, Bayat AA, et al. In vitro assessment of the effects of anti-HER2 monoclonal antibodies on proliferation of HER2-overexpressing breast cancer cells. Immunotherapy. 2014;6(1):43-9.

39. malekpour b, jalalinadoushan m, mansouri s, hadjihosseini r, mirzaei m, jamali d. Comparison of the Killing Effect of Free, Negative and Neutral Charged Liposomal Doxorubicin on Breast Cancer Cell Line (MDA-MB-231). Daneshvar Medicine. 2010;17(85):63-70.

40. Rezaei M, Hashemi M, Hashemi SM, Mashhadi MA, Taheri M. APOBEC3 Deletion is Associated with Breast Cancer Risk in a Sample of Southeast Iranian Population. International journal of molecular and cellular medicine. 2015;4(2):103-8.

41. GALEHDARI HAMID FAM, RASHIDI GOL ROUYEH I.,ANDASHTI B.,FAROKHI ALI,FAZELI GH.R.,NEZARI H.,RASEKH A.A.R. PREVALENCE OF MUTATION IN EXON 2 OF THE BRCA1 GENE AMONG BREAST CANCER PATIENTS AND THEIR HEALTHY RELATIVES IN AHWAZ. Jundishapur Sci Med J.6(4):7.

42. Kooshyar MM, Nassiri MR, Mahdavi M, Doosti M, Parizadeh AR. Identification of germ-line 185delAG BRCA1 mutation among breast cancer families in Iran: An experience from northeastern Iran. Journal of Clinical Oncology. 2013;31(15).

43. Saleh-Gohari N, Mohammadi-Anaie M, Kalantari-Khandani B. BRCA1 Gene Mutations in Breast Cancer Patients from Kerman Province, Iran. Iranian journal of cancer prevention. 2012;5(4):210-5.

44. Tajadini MH, Khadem H, Pourhossein M, Sabzghabaee AM, Hemati S, Sadeghi HMM. Investigating the prevalence of BRCA1 and BRCA2 gene mutations in patients with breast cancer2013. 2217-24 p.

45. Keshavarzi F, Sc M, Reza Javadi G, Nafissi N, Akbarilakeh M, Yassaee V, et al. BRCA1 and BRCA2 genetic testing in breast and/or ovarian cancer families in Iran2010.

46. Ghorbanpoor S BA, Mirmomeni MH, Khazaee S. Role of BRCA1 gene mutations in sporadic cases of breast cancer in Kermanshah. SJKU. $2010 ; 14(4): 12$.

47. Fattahi MJ, Mojtahedi Z, Karimaghaee N, Talei AR, Banani SJ, Ghaderi A. Analysis of BRCA1 and BRCA2 mutations in southern Iranian Breast cancer patients. Archives of Iranian medicine. 2009;12(6):584-7.

48. Sadr-Nabavi A, Dastpak M, Homaei-Shandiz F, Bahrami AR, Bidkhori HR, Raeesolmohaddeseen M. Analysis of novel mutations in BRCA1 in Iranian families with breast cancer. Hereditas. 2014;151(2-3):38-42.

49. Ataei-Kachouei M, Nadaf J, Akbari MT, Atri M, Magewski J, Riazalhosseini Y, et al. Double Heterozygosity of BRCA2 and STK11 in Familial Breast Cancer Detected by Exome Sequencing. Iranian Journal of Public Health. 2015;44(10):1348-52.

50. Pietschmann A, Mehdipour P, Atri M, Hofmann W, Hosseini-AsI SS, Scherneck S, et al. Mutation analysis of BRCA1 and BRCA2 genes in Iranian high risk breast cancer families. Journal of Cancer Research and Clinical Oncology. 2005;131(8):552-8.

51. Kazemi Arababadi M, Mirzaei MR, Rezazadeh Zarandi E, Gholamhossein H, Reza Vatani Baf M. Evaluation of prevalence of $\otimes 32$ mutation in CCR5 gene in breast cancer patients in Rafsanjan city2009.

52. Talaiezadeh A, Jazayeri SN, Nateghi J. Expression of c-kit protein in cancer vs. normal breast tissue. Contemporary oncology (Poznan, Poland). 2012;16(4):306-9.

53. Sadeghi, M, Motovali Bashi M, Hojati Z. ASSOCIATION OF A POLYMORPHISM IN 1562 PROMOTER NUCLEOTIDE OF COLLAGENASES IV WITH THE AGE AND TYPE OF METASTASIS IN BREAST CANCER. Journal of Babol University Of Medical Sciences. 2009;10(6):7-13.

54. Saadatian H, Gharesouran J, Montazeri V, Mohammadi SA, Ardabili SMM. Polymorphism of the cytochrome P-450 1A1 (A2455G) in women with breast cancer in Eastern Azerbaijan, Iran. Iranian Journal of Basic Medical Sciences. 2014;17(3):227-30.

55. Brook A HF, Tavakkol Afshari J, Ganjali R, Afzalaghaee M. Study of Polymorphism of CYP2D6*4 Gene in Susceptibility to Breast Cancer. Armaghan J. 2010;15(4):9.

56. JAMI M.S. TM, HEMATI S. . Association of the length of CA Dinucleotide repeat in the epidermal growth factor receptor with risk and age of breast cancer onset in Isfahan JOURNAL OF ISFAHAN MEDICAL SCHOOL (IUMS). 2008;26(88):9.

57. Abbasi S, Rasouli M, Nouri M, Kalbasi S. Association of estrogen receptor-alpha A908G (K303R) mutation with breast cancer risk. International Journal of Clinical and Experimental Medicine. 2013;6(1):39-49.

58. ABBASI S. AC. Genetic Polymorphisms in the Estrogen Receptor- a Gene codon 325(CCG $\rightarrow$ CCC) and Risk of Breast Cancer among Iranian women: a case control study: S. ABBASI, C. AZIMl; 2009. 75-82 p.

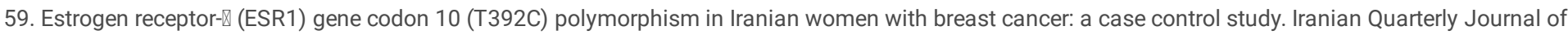
Breast Diseases. 2011;4(3):7-22.

60. Saadatian Z, Gharesouran J, Ghojazadeh M, Ghohari-Lasaki S, Tarkesh-Esfahani N, Ardebili SMM. Association of rs1219648 in FGFR2 and rs1042522 in TP53 with Premenopausal Breast Cancer in an Iranian Azeri Population. Asian Pacific Journal of Cancer Prevention. 2014;15(18):7955-8.

61. Zakieh A, Simin H, Forousan S, Manoochehr T. Polymorphic CT dinucleotide repeat in the GATA3 gene and risk of breast cancer in Iranian women. Medical oncology (Northwood, London, England). 2013;30(2):504.

Page $24 / 31$ 
62. azizian m, yaghmaei b. Breast Cancer And Glutathione s-transferaseGenetic Polymorphism. journal of ilam university of medical sciences. 2009;17(1):318.

63. Hashemi M, Eskandari-Nasab E, Fazaeli A, Taheri M, Rezael H, Mashhadi M, et al. Association between polymorphisms of glutathione S-transferase genes (GSTM1, GSTP1 and GSTT1) and breast cancer risk in a sample Iranian population. Biomarkers in Medicine. 2012;6(6):797-803.

64. Saadat I, Khalili M, Nafissi S, Omidvari S, Saadat M. Susceptibility to breast cancer and three polymorphisms of GSTZ1. DNA and cell biology. 2012;31(3):337-41.

65. Razmkhah M, Ghaderi A. HLA Class I Allele Frequencies in Southern Iranian Women with Breast Cancer. Iran J Basic Med Sci. 2013;16(2):140-3.

66. Amirzargar AA, Mahmoodi M, Nahvi H, Kasaian A, Safari Z, Mahmoudi M, et al. Association study between HLA-DRB, HLA-DQA1, HLA-DQB1 and breast cancer in Iranian women2010.

67. Omrani M, Hashemi M, Eskandari-Nasab E, Hasani SS, Mashhadi MA, Arbabi F, et al. hsa-mir-499 rs3746444 gene polymorphism is associated with susceptibility to breast cancer in an Iranian population. Biomark Med. 2014;8(2):259-67.

68. S JSMTMH. Association between Polymorphic Promoter Region in the IGF-I and Risk of Breast Cancer in Isfahan Area. JOURNAL OF ISFAHAN MEDICAL SCHOOL (IUMS). 2011;28(119):9.

69. Amirzargar AA, Naroueynejad M, Khosravi F, Dianat S, Rezaei N, Mytilineos J, et al. Cytokine single nucleotide polymorphisms in Iranian populations. European Cytokine Network. 2008;19(2):104-12.

70. Rostami S, Kohan L, Mohammadianpanah M. The LEP G-2548A gene polymorphism is associated with age at menarche and breast cancer susceptibility. Gene. 2015;557(2):154-7.

71. Tatari F, Salek R, Mosaffa F, Khedri A, Behravan J. Association of C3435T single-nucleotide polymorphism of MDR1 gene with breast cancer in an Iranian population. DNA and cell biology. 2009;28(5):259-63.

72. Taheri M, Mahjoubi F, Omranipour R, Fereidouni F. Investigation of C3435T Polymorphism in MDR1 Gene of Breast Cancer Patients. Zahedan Journal of Research in Medical Sciences. 2009;11(3):0-

73. Rahmani B, Azimi C, Omranipour R, Raoofian R, Zendehdel K, Saee-Rad S, et al. Mutation screening in the mitochondrial D-loop region of tumoral and nontumoral breast cancer in Iranian patients. Acta medica Iranica. 2012;50(7):447-53.

74. Hosseini M. Role of Polymorphism of Methyltetrahydrofolatehomocysteine Methyltransfrase (MTR) A2756G and Breast Cancer Risk. Polish Journal of Pathology. 2013;64(3):191-5.

75. Doosti A, Dehkordi PG, Davoudi N. A p53 codon 72 polymorphism associated with breast cancer in Iranian patients. African Journal of Pharmacy and Pharmacology. 2011;5(10):1278-81.

76. Khani H, Hosseinpourefeizi M, Pouladi N, Chaparzadeh N, Montazeri V, Azarfam P. Detection of p53 gene exons 5 and 6 mutations among East Azerbaijani women with breast cancer2012.

77. Faghani M, Nasiri E, Bahadori MH, Mohammad Ghasemi F. Genetic Predisposing of P53 Codon 72 on Developing of Breast Cancer in Postmenopausal Women in Isfahan. Journal of Guilan University of Medical Sciences. 2008;17(67):94-100.

78. Pouladi N, Kouhsari SM, Feizi MH, Dehghan R, Azarfam P, Farajzadeh D. Lack of association of intron 316 bp polymorphism of TP53 with breast cancer among Iranian-Azeri patients. Asian Pacific journal of cancer prevention : APJCP. 2014;15(6):2631-4.

79. Mofid B, Eshraghi P, Daneshpour M, Hedayati M. PTEN polymorphism (IVS4) in breast cancer in Iranian women2010. 179-82 p.

80. Pirouzpanah S, Taleban FA, Atri M, Abadi AR, Mehdipour P. The effect of modifiable potentials on hypermethylation status of retinoic acid receptor-beta2 and estrogen receptor-alpha genes in primary breast cancer. Cancer causes \& control : CCC. 2010;21(12):2101-11.

81. Razmkhah M, Talei AR, Doroudchi M, Khalili-Azad T, Ghaderi A. Stromal cell-derived factor-1 (SDF-1) alleles and susceptibility to breast carcinoma. Cancer letters. 2005;225(2):261-6.

82. Kyani K, Feizi MAH, Babaei E, Montazeri V, Halimi M. STUDY OF THE EXPRESSION OF SURVIVIN \& ITS SPLICE VARIANTS; $\triangle$ EX3, 2B AND 3B AS DIAGNOSTIC MOLECULAR MARKERS IN BREAST CANCER2009.

83. Amani D, Khalilnezhad A, Ghaderi A, Niikawa N, Yoshiura K. Transforming growth factor beta1 (TGF beta 1) polymorphisms and breast cancer risk. Tumor Biology. 2014;35(5):4757-64.

84. Hossein Pour Feizi MA, Ravanbakhsh R, Pourahmad R, Pouladi N, Azarfam P, Montazeri V. Association of p53 Arg/Pro polymorphism at Codon 72 with risk of breast cancer in east Azerbaijani women2012. 31-8 p.

85. Shahbazi S, Alavi S, Majidzadeh AK, Ghaffarpour M, Soleimani A, Mahdian R. Bsml but not Fokl polymorphism of VDR gene is contributed in breast cancer. Medical oncology (Northwood, London, England). 2013;30(1):393.

86. Sedaie Bonab A, Pouladi N, Hosseinpourfeizi MA, Ravanbakhsh Gavgani R, Dehghan R, Azarfam P, et al. Single-strand conformational polymorphism analysis of a common single nucleotide variation in WRAP53 gene, rs2287499, and evaluating its association in relation to breast cancer risk and prognosis among Iranian-Azeri population. Medical oncology (Northwood, London, England). 2014;31(9):168.

87. Saadat M, Kohan L, Omidvari S. Genetic polymorphisms of XRCC1 (codon 399) and susceptibility to breast cancer in Iranian women, a case-control study. Breast cancer research and treatment. 2008;111(3):549-53.

88. Rajaei M, Saadat I, Omidvari S, Saadat M. Association between polymorphisms at promoters of XRCC5 and XRCC6 genes and risk of breast cancer. Medical oncology (Northwood, London, England). 2014;31(4):885.

89. Nasiri M, Saadat I, Omidvari S, Saadat M. Genetic variation in DNA repair gene XRCC7 (G6721T) and susceptibility to breast cancer. Gene. 2012;505(1):195-7.

Page 25/31 
90. Mirzaei MH, Noruzinia M, Karbassian H, Shafeghati Y, Keyhanee M, Bidmeshki-Pour A. Evaluation of Methylation Status in the 5'UTR Promoter Region of the DBC2 Gene as a Biomarker in Sporadic Breast Cancer. Cell Journal. 2012;14(1):19-24.

91. Sadeq V, Isar N, Manoochehr T. Association of sporadic breast cancer with PTEN/MMAC1/TEP1 promoter hypermethylation. Medical oncology (Northwood, London, England). 2011;28(2):420-3.

92. Identification of BRCA1 and BRCA2 mutations in a number of Iranian patients with early onset breast cancer or family history of breast cancer risk. Iranian Quarterly Journal of Breast Diseases. 2009;2(2):14-26.

93. Rahimi Z, Yari K, Rahimi Z. Matrix metalloproteinase-9 -1562T allele and its combination with MMP-2 -735 C allele are risk factors for breast cancer. Asian Pacific journal of cancer prevention : APJCP. 2015;16(3):1175-9.

94. Keshavarzi F, Nafissi N, Sirati F, Fallah MS, Salehi R, Harriry Z, et al. The occurrence and contribution of germline BRCA1/2 sequence alterations in Iranian patients with breast cancer. Tehran University Medical Journal. 2011;69(9):559-70.

95. Hossein Pour Feizi M, Taghizadeh S, Pouladi N, Azarfam P, Montazeri V. Study of MDM2 Promoter Polymorphism(SNP309) in Breast Cancer Patients in an Iranian Population. The Journal of Shahid Sadoughi University of Medical Sciences. 2011;19(3):359-68.

96. Eskandari A, Jaberipour M, khodadadi A, Ghaderi A. IL-23 and IL-27 gene expression in three breast cancer cell lines and metastatic and non-metastatic lymph nodes in breast cancer patients. koomesh Journal. 2011;12(4):428-34.

97. Zekri A, Lesan V, Ghaffari SH, Tabrizi MH, Modarressi MH. Gene amplification and overexpression of Aurora-C in breast and prostate cancer cell lines. Oncology research. 2012;20(5-6):241-50.

98. Bahmani P, Hassanshahi G, Halabian R, Roushandeh AM, Jahanian-Najafabadi A, Roudkenar MH. The Expression of Heme Oxygenase-1 in HumanDerived Cancer Cell Lines. Iranian Journal of Medical Sciences. 2011;36(4):260-5.

99. Homaei-Shandiz F, Ghavam-Nassiri MR, Sharifi N, Homaei-Shandiz AH, Taghizadeh-Kermani A, Torshizi SAM, et al. Evaluation of the relationship between human epidermal growth factor receptor-2/neu (c-erbB-2) amplification and pathologic grading in patients with breast cancer. Saudi Medical Journal. 2006;27(12):1810-4.

100. Saadat M, Khalili M, Nasiri M, Rajaei M, Omidvari S, Saadat I. Clinical response to chemotherapy in locally advanced breast cancer was not associated with several polymorphisms in detoxification enzymes and DNA repair genes. Biochemical and biophysical research communications. 2012;419(1):117-9.

101. Sadeghi M, Motovali-Bashi M, Hojati Z. MMP-9 promoter polymorphism associated with tumor progression of breast cancer in Iranian population. International Journal of Integrative Biology. 2009;6(1):33-7.

102. Salimi M, Mozdarani H, Majidzadeh K. Expression pattern of ATM and cyclin D1 in ductal carcinoma, normal adjacent and normal breast tissues of Iranian breast cancer patients. Medical oncology (Northwood, London, England). 2012;29(3):1502-9.

103. Seghatoleslam A, Nikseresht M, Shafiee SM, Monabati A, Namavari MM, Talei A, et al. Expression of the novel human gene, UBE2Q1, in breast tumors. Molecular biology reports. 2012;39(5):5135-41.

104. Shafiee SM, Rasti M, Seghatoleslam A, Azimi T, Owji AA. UBE2Q1 in a Human Breast Carcinoma Cell Line: Overexpression and Interaction with p53. Asian Pacific journal of cancer prevention : APJCP. 2015;16(9):3723-7.

105. Sharifi S, Barar J, Hejazi MS, Samadi N. Roles of the Bcl-2/Bax ratio, caspase-8 and 9 in resistance of breast cancer cells to paclitaxel. Asian Pacific journal of cancer prevention : APJCP. 2014;15(20):8617-22.

106. Tabarestani S, Ghaderian SM, Rezvani H, Mirfakhraie R. Expression profiling of breast cancer patients treated with tamoxifen: prognostic or predictive significance. Medical oncology (Northwood, London, England). 2014;31(4):896.

107. Taheri M, Mahjoubi F, Omranipour R. Effect of MDR1 polymorphism on multidrug resistance expression in breast cancer patients. Genetics and molecular research : GMR. 2010;9(1):34-40.

108. Taherian A, Zadeh SMM, Ghani H, Khamechian T. ST6Gal1, Cox-2 and HB-EGF mRNA expression in breast cancer samples from Kashan, Iran. Middle East Journal of Cancer. 2015;6(1):43-50.

109. Vallian S, Sedaghat M, Nassiri I, Frazmand A. Methylation status of p16 INK4A tumor suppressor gene in Iranian patients with sporadic breast cancer. J Cancer Res Clin Oncol. 2009;135(8):991-6.

110. Khazan N, Ghavamzadeh A, Boyajyan A, Mkrtchyan G, Alimoghaddam K, Ghaffari SH. The Detection Of Micrometastases In Peripheral Blood And Bone Marrow Of Breast Cancer Patients Using Marker(MUC2) Real Time PCR Payavard Salamat. 2012;6(2):89-100.

111. Pirouzpanah S, Taleban F, Abadi A, Atri M, Mehdipour P. The Association of Plasma Folate, Vitamin B12 and Homocysteine Levels on Hypermethylation Status of RARß2 Gene in Primary Breast Carcinoma. Iranian Journal of Epidemiology. 2009;5(2):19-27.

112. Nassiri I, Faghihi M, Tavassoli M. Pharmacogenomic profiling of the PI3K/PTEN pathway in sporadic breast cancer. Iranian biomedical journal. 2009;13(2):79-86.

113. Amani D, Hassan ZM, Ravangard F, Frazmand S, Karim Zadeh M. Flowcytometric Analysis of Tumor Associated Macrophages in Invasive Ductal Carcinoma of Breast. Iranian Journal of Immunology. 2005;2(2):117-22.

114. Poursadegh Zonouzi AA, Nejatizadeh A, Rahmati-Yamchi M, Fardmanesh H, Shakerizadeh S, Poursadegh Zonouzi A, et al. Dysregulated expression of Dicer in invasive ductal breast carcinoma. Medical oncology (Northwood, London, England). 2015;32(7):203.

115. B R, Z M, M K, S M. The immunohistochemical assessment of ALDH1 activity in breast cancer and it's correlation with pathologic features. Tehran University Medical Journal. 2011;69(9):529-36.

116. M Negahdar MD, H Abtahi , MR Sadeghi , T Aghvami , E Javadi , H Layegh Blood Superoxide Dismutase and Catalase Activities in Women Affected with Breast Cancer. Iranian J Publ Health. 2005;34(3):5. 
117. Golmohammadi R, Pejhan A Gene experison of cell proliferative marker Ki67 in breast cancer. Journal of Gorgan University of Medical Sciences. 2011;13(3):65-71.

118. Pejhan A, Golmohammadi R. P53 GENE EXPRESSION WITH HISTOPATHOLOGICAL PARAMETERS IN BREAST CANCER PATIENTS. Journal of Sabzevar University of Medical Sciences. 1970;17(2):123-8.

119. Yazdi MF, Rafieian S, Gholi-Nataj M, Sheikhha MH, Nazari T, Neamatzadeh H. CYP2D6 Genotype and Risk of Recurrence in Tamoxifen Treated Breast Cancer Patients. Asian Pacific journal of cancer prevention : APJCP. 2015;16(15):6783-7.

120. Panahi M, Saki N, Ashourzadeh S, Rahim F. Expressional correlation of human epidermal growth factor receptor 2, estrogen/progesterone receptor and protein 53 in breast cancer. Asian Pacific journal of cancer prevention : APJCP. 2013;14(6):3699-703.

121. Haghighi F, Hashemzehi M, Saadatjoo S. Prevalence of P53 gene mutations, estrogen and progesterone in breast cancer patients. Quarterly of Horizon of Medical Sciences. 2006;12(2):5-10.

122. Ashrafi M, Bathaie SZ, Abroun S, Azizian M. Effect of Crocin on Cell Cycle Regulators in N-Nitroso-N-Methylurea-Induced Breast Cancer in Rats. DNA and cell biology. 2015;34(11):684-91.

123. Hamedeyazdan S, Fathiazad F, Sharifi S, Nazemiyeh H. Antiproliferative Activity of Marrubium persicum Extract in the MCF-7 Human Breast Cancer Cell Line. Asian Pacific Journal of Cancer Prevention. 2012;13(11):5843-8.

124. Ostad SN, Dehnad S, Nazari ZE, Fini ST, Mokhtari N, Shakibaie M, et al. Cytotoxic Activities of Silver Nanoparticles and Silver lons in Parent and Tamoxifen-Resistant T47D Human Breast Cancer Cells and Their Combination Effects with Tamoxifen against Resistant Cells. Avicenna journal of medical biotechnology. 2010;2(4):187-96.

125. Panjehpour M, Taher MA, Bayesteh M. The growth inhibitory effects of cadmium and copper on the MDA-MB468 human breast cancer cells. Journal of research in medical sciences : the official journal of Isfahan University of Medical Sciences. 2010;15(5):279-86.

126. Pirouzpanah MB, Sabzichi M, Pirouzpanah S, Chavoshi H, Samadi N. Silibilin-induces apoptosis in breast cancer cells by modulating p53, p21, Bak and Bcl-XL pathways. Asian Pacific journal of cancer prevention : APJCP. 2015;16(5):2087-92.

127. Rajabi M. 2-(3,5-Dihydroxyphenyl)-6-hydroxybenzothiazole arrests cell growth and cell cycle and induces apoptosis in breast cancer cell lines. DNA and cell biology. 2012;31(3):388-91.

128. Rajabi M, Khalilzadeh MA, Mehrzad J. Antiproliferative activity of novel derivative of thiopyran on breast and colon cancer lines and DNA binding. DNA and cell biology. 2012;31(1):128-34.

129. Rajabi M, Khalilzadeh MA, Tavakolinia F, Signorelli P, Ghidoni R, Santaniello E. Naphthalene-fused (alpha-alkoxycarbonyl)methylene-gammabutyrolactones: antiproliferative activity and binding to bovine serum albumin and DNA. DNA and cell biology. 2012;31(5):783-9.

130. Rajabi M, Minutolo F, Bertini S, Macchia M, Ghidoni R. Antiproliferative activity and cell cycle analysis of 2-(3,5-dihydroxyphenyl)-6-hydroxybenzothiazole on MCF-7 breast and HCT-15 colon cancer cell lines. DNA and cell biology. 2011;30(8):617-21.

131. Rezaei PF, Fouladdel S, Ghaffari SM, Amin G, Azizi E. Induction of G1 cell cycle arrest and cyclin D1 down-regulation in response to pericarp extract of Baneh in human breast cancer T47D cells. Daru : journal of Faculty of Pharmacy, Tehran University of Medical Sciences. 2012;20(1):101.

132. Rezakhani L, Rashidi Z, Mirzapur P, Khazaei M. Antiproliferatory Effects of Crab Shell Extract on Breast Cancer Cell Line (MCF7). Journal of breast cancer. 2014;17(3):219-25.

133. Rouhani M, Goliaei B, Khodagholi F, Nikoofar A. Lithium increases radiosensitivity by abrogating DNA repair in breast cancer spheroid culture. Archives of Iranian medicine. 2014;17(5):352-60.

134. Rouhani M, Goliaei B, Khodagholi F, Nikoofar A. Antimanic drug sensitizes breast cancer cell line to ionizing radiation. General physiology and biophysics. 2014;33(2):235-42.

135. Sabzichi M, Hamishehkar H, Ramezani F, Sharifi S, Tabasinezhad M, Pirouzpanah M, et al. Luteolin-loaded phytosomes sensitize human breast carcinoma MDA-MB 231 cells to doxorubicin by suppressing Nrf2 mediated signalling. Asian Pacific journal of cancer prevention : APJCP. 2014;15(13):5311-6.

136. Sadeghnia HR, Ghorbani Hesari T, Mortazavian SM, Mousavi SH, Tayarani-Najaran Z, Ghorbani A. Viola tricolor induces apoptosis in cancer cells and exhibits antiangiogenic activity on chicken chorioallantoic membrane. 2014;2014:625792.

137. Sadighi S, Amanpour S, Behrouzi B, Khorgami Z, Muhammadnejad S. Lack of metformin effects on different molecular subtypes of breast cancer under normoglycemic conditions: an in vitro study. Asian Pacific journal of cancer prevention : APJCP. 2014;15(5):2287-90.

138. Sadjadpour S, Safarian S, Zargar SJ, Sheibani N. Antiproliferative effects of ZnO, ZnO-MTCP, and ZnO-CuMTCP nanoparticles with safe intensity UV and X-ray irradiation. Biotechnology and applied biochemistry. 2015.

139. Saeidifar M, Mansouri-Torshizi H, Palizdar Y, Divsalar A, Saboury AA. Synthesis, characterization, and cytotoxicity studies of a novel palladium(II) complex and evaluation of DNA-binding aspects. Nucleosides, nucleotides \& nucleic acids. 2013;32(7):366-88.

140. Saffari Z, Zarabi MF, Aryapour H, Foroumadi A, Farhangi A, Ghassemi S, et al. Cytotoxicity and Apoptosis Inducing Activities of 2-Amino-4H-chromene-3carbonitrile Derivatives Loaded on Gold Nanoparticles Against Human Breast Cancer Cell Line T47D. Indian journal of clinical biochemistry : IJCB. 2015;30(2):140-9.

141. Sajadian S, Vatankhah M, Majdzadeh M, Kouhsari SM, Ghahremani MH, Ostad SN. Cell cycle arrest and apoptogenic properties of opium alkaloids noscapine and papaverine on breast cancer stem cells. Toxicology mechanisms and methods. 2015;25(5):388-95.

142. Salimi M, Abdi K, Kandelous HM, Hadadzadeh H, Azadmanesh K, Amanzadeh A, et al. Antiproliferative effects of copper(II)-polypyridyl complexes in breast cancer cells through inducing apoptosis. Biometals : an international journal on the role of metal ions in biology, biochemistry, and medicine. 2015;28(2):267-78.

Page 27/31 
143. Samarghandian S, Hadjzadeh MA, Afshari JT, Hosseini M. Antiproliferative activity and induction of apoptotic by ethanolic extract of Alpinia galanga rhizhome in human breast carcinoma cell line. BMC complementary and alternative medicine. 2014;14:192.

144. Saravani R, Karami-Tehrani F, Hashemi M, Aghaei M, Edalat R. Inhibition of phosphodiestrase 9 induces cGMP accumulation and apoptosis in human breast cancer cell lines, MCF-7 and MDA-MB-468. Cell proliferation. 2012;45(3):199-206.

145. Sattarinezhad E, Bordbar AK, Fani N. Piperine derivatives as potential inhibitors of Survivin: An in silico molecular docking. Computers in biology and medicine. 2015;63:219-27.

146. Sazgarnia A, Montazerabadi AR, Bahreyni-Toosi MH, Ahmadi A, Aledavood A. In vitro survival of MCF-7 breast cancer cells following combined treatment with ionizing radiation and mitoxantrone-mediated photodynamic therapy. Photodiagnosis and photodynamic therapy. 2013;10(1):72-8.

147. Seifi-Alan M, Shamsi R, Ghafouri-Fard S, Mirfakhraie R, Zare-Abdollahi D, Movafagh A, et al. Expression analysis of two cancer-testis genes, FBXO39 and TDRD4, in breast cancer tissues and cell lines. Asian Pacific journal of cancer prevention : APJCP. 2014;14(11):6625-9.

148. Sepehri N, Rouhani H, Tavassolian F, Montazeri H, Khoshayand MR, Ghahremani MH, et al. SN38 polymeric nanoparticles: in vitro cytotoxicity and in vivo antitumor efficacy in xenograft balb/c model with breast cancer versus irinotecan. International journal of pharmaceutics. 2014;471(1-2):485-97.

149. Shadi S, Saeidi H, Ghanadian M, Rahimnejad MR, Aghaei M, Ayatollahi SM, et al. New macrocyclic diterpenes from Euphorbia connata Boiss. with cytotoxic activities on human breast cancer cell lines. Natural product research. 2015;29(7):607-14.

150. Shahbazfar AA, Zare P, Ranjbaran M, Tayefi-Nasrabadi H, Fakhri O, Farshi Y, et al. A survey on anticancer effects of artemisinin, iron, miconazole, and butyric acid on 5637 (bladder cancer) and 4T1 (Breast cancer) cell lines. Journal of cancer research and therapeutics. 2014;10(4):1057-62.

151. Shahbazian S, Akbarzadeh A, Torabi S, Omidi M. Anti-cancer activity of pegylated liposomal trans-anethole on breast cancer cell lines MCF-7 and T47D. Biotechnology letters. 2015;37(7):1355-9.

152. Shahrokhi S, Daneshmandi S, Menaa F. Tumor necrosis factor-alpha/CD40 ligand-engineered mesenchymal stem cells greatly enhanced the antitumor immune response and lifespan in mice. Human gene therapy. 2014;25(3):240-53.

153. Shoae-Hassani A, Mortazavi-Tabatabaei SA, Sharif S, Madadi S, Rezaei-Khaligh H, Verdi J. Recombinant lambda bacteriophage displaying nanobody towards third domain of HER-2 epitope inhibits proliferation of breast carcinoma SKBR-3 cell line. Archivum immunologiae et therapiae experimentalis. 2013;61(1):75-83.

154. Tabrizi L, Chiniforoshan H, McArdle P. Synthesis, crystal structure and spectroscopy of bioactive Cd(II) polymeric complex of the non-steroidal antiinflammatory drug diclofenac sodium: antiproliferative and biological activity. Spectrochimica acta Part A, Molecular and biomolecular spectroscopy. 2015;136 Pt B:429-36.

155. Taghizadeh B, Ghavami L, Nikoofar A, Goliaei B. Equol as a potent radiosensitizer in estrogen receptor-positive and -negative human breast cancer cell lines. Breast cancer (Tokyo, Japan). 2015;22(4):382-90.

156. Taheri A, Dinarvand R, Ahadi F, Khorramizadeh MR, Atyabi F. The in vivo antitumor activity of LHRH targeted methotrexate-human serum albumin nanoparticles in 4T1 tumor-bearing Balb/c mice. International journal of pharmaceutics. 2012;431(1-2):183-9.

157. Taheri FH, Seyedolmohadesin M, Bayat M, Mahdavi M, Yazdi MH, Eslamifar A, et al. The effect of candida albicans systemic infection on matrix metalloproteinases in breast cancer bearing balb/c mice. Iranian Journal of Allergy, Asthma and Immunology. 2013;12(1):81-5.

158. Taherian A, Mazoochi T. Different Expression of Extracellular Signal-Regulated Kinases (ERK) $1 / 2$ and Phospho-Erk Proteins in MBA-MB-231 and MCF-7 Cells after Chemotherapy with Doxorubicin or Docetaxel. Iran J Basic Med Sci. 2012;15(1):669-77.

159. Tahoori F, Sheikhnejad R, Balalaie S, Sadjadi M. Synthesis of novel peptides through Ugi-ligation and their anti-cancer activities. Amino acids. 2013;45(4):975-81.

160. Talaei F, Azizi E, Dinarvand R, Atyabi F. Thiolated chitosan nanoparticles as a delivery system for antisense therapy: evaluation against EGFR in T47D breast cancer cells. International journal of nanomedicine. 2011;6:1963-75.

161. Tavakoli Yaraki M, Karami Tehrani F. Apoptosis Induced by 13-S-hydroxyoctadecadienoic acid in the Breast Cancer Cell Lines, MCF-7 and MDA-MB-231. Iran J Basic Med Sci. 2013;16(4):661-9.

162. Tavakoli-Yaraki M, Karami-Tehrani F, Salimi V, Sirati-Sabet M. Induction of apoptosis by Trichostatin A in human breast cancer cell lines: involvement of 15-Lox-1. Tumour biology : the journal of the International Society for Oncodevelopmental Biology and Medicine. 2013;34(1):241-9.

163. Tayarani-Najaran Z, Asili J, Aioubi E, Emami SA. Growth Inhibition and Apoptosis Induction of Salvia chloroleuca on MCF-7 Breast Cancer Cell Line. Iranian journal of pharmaceutical research : IJPR. 2013;12(4):789-99.

164. Tekie FS, Atyabi F, Soleimani M, Arefian E, Atashi A, Kiani M, et al. Chitosan polyplex nanoparticle vector for miR-145 expression in MCF-7: Optimization by design of experiment. International journal of biological macromolecules. 2015;81:828-37.

165. Tila D, Yazdani-Arazi SN, Ghanbarzadeh S, Arami S, Pourmoazzen Z. pH-sensitive, polymer modified, plasma stable niosomes: promising carriers for anticancer drugs. EXCLI journal. 2015;14:21-32.

166. Vafaiyan Z, Gharaei R, Asadi J. The correlation between telomerase activity and Bax/Bcl-2 ratio in valproic acid-treated MCF-7 breast cancer cell line. Iran J Basic Med Sci. 2015;18(7):700-4.

167. Valiyari S, Baradaran B, Delazar A, Pasdaran A, Zare F. Dichloromethane and Methanol Extracts of Scrophularia oxysepala Induces Apoptosis in MCF-7 Human Breast Cancer Cells. Advanced pharmaceutical bulletin. 2012;2(2):223-31.

168. Yazdanpanahi N, Behbahani M, Yektaeian A. Effect of boswellia thurifera gum methanol extract on cytotoxicity and p53 gene expression in human breast cancer cell line. BioMed research international. 2014;13(2):719-24.

169. Yazdi M, Najafi ZN, Khorramizadeh M, Amini M, Shahverdi A. Fabrication of docetaxel surfaced Fe304 magnetite nanoparticles and their cytotoxicity on 4 T1 breast cancer cells. Daru : journal of Faculty of Pharmacy, Tehran University of Medical Sciences. 2012;20(1):15.

Page 28/31 
170. Yazdi MH, Mahdavi M, Setayesh N, Esfandyar M, Shahverdi AR. Selenium nanoparticle-enriched Lactobacillus brevis causes more efficient immune responses in vivo and reduces the liver metastasis in metastatic form of mouse breast cancer. Daru : journal of Faculty of Pharmacy, Tehran University of Medical Sciences. 2013;21(1):33.

171. Yazdi MH, Mahdavi M, Varastehmoradi B, Faramarzi MA, Shahverdi AR. The immunostimulatory effect of biogenic selenium nanoparticles on the 4T1 breast cancer model: an in vivo study. Biological trace element research. 2012;149(1):22-8

172. Yousefi F, Mousavi SF, Siadat SD, Aslani MM, Amani J, Rad HS, et al. Preparation and In Vitro Evaluation of Antitumor Activity of TGFalphaL3-SEB as a Ligand-Targeted Superantigen. Technology in cancer research \& treatment. 2015.

173. Zeighamian V, Darabi M, Akbarzadeh A, Rahmati-Yamchi M, Zarghami N, Badrzadeh F, et al. PNIPAAm-MAA nanoparticles as delivery vehicles for curcumin against MCF-7 breast cancer cells. Artificial cells, nanomedicine, and biotechnology. 2015:1-8.

174. Zekri A, Ghaffari SH, Yousefi M, Ghanizadeh-Vesali S, Mojarrad M, Alimoghaddam K, et al. Autocrine human growth hormone increases sensitivity of mammary carcinoma cell to arsenic trioxide-induced apoptosis. Molecular and cellular endocrinology. 2013;377(1-2):84-92.

175. B G, Hassan Z M, Ghaderi Pakdel F, S Z. Synergistic Inhibition of Lactobacillus Rhamnosus and Cisplatin on the Multiplication of Tumoral Cells in BALB/C Mice with Breast Cancer2011. 701-10 p.

176. Mahmoodi N, Paylakhi S, Motamed. Survey the effect of silybin on HER2 in SKBR3 breast cancer cell line2012.

177. Gordanian B, Behbahani M, Carapetian J, Fazilati M. Cytotoxic effect of Artemisia absinthium L. grown at two different altitudes on human breast cancer cell line MCF7. Pejouhesh dar Pezeshki (Research in Medicine). 2012;36(3):124-31.

178. Safarian S, Mohammadpour R, Ejheian F, Abdolmohammadi MH. Study of the Effects of Acetazolamide on Decreasing Viability of Breast Cancer Cells in T-47D Cell Line. Qom Univ Med Sci J. 2011;5(1):61-74.

179. Momtazi AA, Behbahani M, Sadeghi-Aliabadi H. Evalution of cytotoxic effect of some extracts of Avicennia marina against MDA-MB 231 human breast cancer cell line2011. 229-38 p.

180. Sadeghi-Aliabadi H, Karimimanesh A, Varshosaz J. Biological effects of letrozole-loaded lipid nanocapsules on MCF-7 Cell line2013. $2169-77$ p.

181. Morshedi A, Delirezh N, Parvin P, Mokarizade A. Evaluating The Effect of Melphalan-induced Damaged DNA on Expression of Maturity Markers and Polarization of Immune Phenotypes of Dendritic Cells. Urmia Medical Journal. 2012;23(3):304-14.

182. Tavakkol Afshari J, Moheghi N, Brook A. Ethanolic Extract Cytotoxic Effect of Zingiber Afficinale in Breast Cancer (MCF7) Cell Line. Armaghane danesh. 2010;15(2):115-24.

183. Arezoomand R, Zarghami N, Rahmati M, Pourhassan-Moghaddam M, Nejati-Koshki K, Delazar A, et al. The inhibitory effect of curcuma longa total extract on telomerase gene expression and activity in MCF-7 breast cancer cell line2010. 131-8 p.

184. Mousavi SH, Afshari J, Brook A. Study of Cytotoxic Effects of Saffron in MCF-7 Cells2018.

185. Soltan-Dallal M, Shirazi L, Yazdi M, Mahdavi M, Mokarrari S, Rahimi Forushani A, et al. Effect of oral administration of Lactobacillus reuteri in increased survival and resistance to neoplasm in mice breast cancer2013. 700-8 p.

186. Shalamzari SA, Agha-Alinejad H, Alizadeh S, Shahbazi S, Khatib ZK, Kazemi A, et al. The effect of exercise training on the level of tissue IL-6 and vascular endothelial growth factor in breast cancer bearing mice. Iran J Basic Med Sci. 2014;17(4):231-58.

187. Soltani F, Sankian M, Hatefi A, Ramezani M. Development of a novel histone H1-based recombinant fusion peptide for targeted non-viral gene delivery. International journal of pharmaceutics. 2013;441(1-2):307-15.

188. Shariat S, Badiee A, Amir Jalali S, Mansourian M, Alireza Mortazavi S, Reza Jaafari M. Preparation and characterization of different liposomal formulations containing P5 HER2/neu-derived peptide and evaluation of their immunological responses and antitumor effects. Iran J Basic Med Sci. 2015;18(5):506-13.

189. Shanehsazzadeh S, Gruettner C, Lahooti A, Mahmoudi M, Allen BJ, Ghavami M, et al. Monoclonal antibody conjugated magnetic nanoparticles could target MUC-1-positive cells in vitro but not in vivo. Contrast media \& molecular imaging. 2015;10(3):225-36.

190. Rahmani-Nezhad S, Safavi M, Pordeli M, Ardestani SK, Khosravani L, Pourshojaei Y, et al. Synthesis, in vitro cytotoxicity and apoptosis inducing study of 2-aryl-3-nitro-2H-chromene derivatives as potent anti-breast cancer agents. European journal of medicinal chemistry. 2014;86:562-9.

191. khaleghi s, rahbarizadeh f, Azadmanesh K, Rasaiee MJ, Jafari F. Synthesis of chimeric T cell receptor with OX40 co-stimulatory receptor targeted against breast cancer cells. Daneshvar Medicine. 2011;19(95):1-8.

192. Soltan-Dallal M, Yazdi M, Hassan ZM, Holakuyee M, P. Abedi Mohtasab T, Aminharaty F, et al. Effect of oral administration of lactobacillus acidophilus on the immune responses and survival of BALB/c mice bearing human breast cancer2010. 753-8 $p$.

193. Pakravan N, Hassan ZM. Comparison of adjuvant activity of N-and C-terminal domain of gp96 in a Her2-positive breast cancer model. Cell stress \& chaperones. 2011;16(4):449-57.

194. Pakravan N, Langroudi L, Hajimoradi M, Hassan ZM. Co-administration of GP96 and Her2/neu DNA vaccine in a Her2 breast cancer model. Cell stress \& chaperones. 2010;15(6):977-84.

195. Pouyanfard S, Bamdad T, Hashemi H, Bandehpour M, Kazemi B. Induction of protective anti-CTL epitope responses against HER-2-positive breast cancer based on multivalent T7 phage nanoparticles. PloS one. 2012;7(11):e49539.

196. Rafinejad A, Fallah-Tafti A, Tiwari R, Shirazi AN, Mandal D, Shafiee A, et al. 4-Aryl-4H-naphthopyrans derivatives: one-pot synthesis, evaluation of Src kinase inhibitory and anti-proliferative activities. Daru : journal of Faculty of Pharmacy, Tehran University of Medical Sciences. 2012;20(1):100.

197. Razmkhah M, Jaberipour M, Hosseini A, Safaei A, Khalatbari B, Ghaderi A. Expression profile of IL-8 and growth factors in breast cancer cells and adiposederived stem cells (ASCs) isolated from breast carcinoma. Cellular immunology. 2010;265(1):80-5. 
198. Razmkhah M, Jaberipour M, Erfani N, Habibagahi M, Talei AR, Ghaderi A. Adipose derived stem cells (ASCs) isolated from breast cancer tissue express IL4, IL-10 and TGF-beta1 and upregulate expression of regulatory molecules on T cells: do they protect breast cancer cells from the immune response? Cellular immunology. 2011;266(2):116-22.

199. Rahbarizadeh F, Rasaee MJ, Forouzandeh M, Allameh A, Sarrami R, Nasiry H, et al. The production and characterization of novel heavy-chain antibodies against the tandem repeat region of MUC1 mucin. Immunological investigations. 2005;34(4):431-52.

200. Sadri-Ardalani F, Shabani M, Amiri MM, Bahadori M, Emami S, Sarrafzadeh AR, et al. Antibody response to HER2 extracellular domain and subdomains in mouse following DNA immunization. Tumour biology : the journal of the International Society for Oncodevelopmental Biology and Medicine. 2015.

201. Razmkhah M, Abedi N, Hosseini A, Imani MT, Talei AR, Ghaderi A. Induction of T regulatory subsets from naive CD4+ T cells after exposure to breast cancer adipose derived stem cells. Iranian journal of immunology : IJI. 2015;12(1):1-15.

202. Mozdarani H, Mashhadi AHZ, Alimohammadi Z. G(2) chromosomal radiosensitivity and background frequency of sister chromatid exchanges of peripheral blood lymphocytes of breast cancer patients. Iranian Journal of Radiation Research. 2011;9(3):167-74.

203. Shahidi M, Mozdarani S, Shammas S. Interindividual differences in radiation-induced apoptosis of peripheral blood leukocytes in normal individuals and breast cancer patients. Iranian Journal of Radiation Research. 2012;9(4):237-44.

204. Sun J, Yu CH, Zhao XL, Wang Y, Jiang SG, Gong XF. Econazole Nitrate Induces Apoptosis in MCF-7 Cells via Mitochondrial and Caspase Pathways. Iranian journal of pharmaceutical research : IJPR. 2014;13(4):1327-34.

205. Sajadimajd S, Yazdanparast R. Differential behaviors of trastuzumab-sensitive and -resistant SKBR3 cells treated with menadione reveal the involvement of Notch1/Akt/FOX01 signaling elements. Molecular and cellular biochemistry. 2015;408(1-2):89-102.

206. Rad FR, Ajdary S, Omranipour R, Alimohammadian MH, Hassan ZM. Comparative analysis of CD4+ and CD8+ T cells in tumor tissues, lymph nodes and the peripheral blood from patients with breast cancer. Iranian biomedical journal. 2015;19(1):35-44.

207. Pornour M, Ahangari G, Hejazi SH, Deezagi A. New perspective therapy of breast cancer based on selective dopamine receptor d2 agonist and antagonist effects on mcf-7 cell line. Recent patents on anti-cancer drug discovery. 2015;10(2):214-23.

208. Panjehpour M, Karami-Tehrani F. Adenosine modulates cell growth in the human breast cancer cells via adenosine receptors. Oncology research. 2007;16(12):575-85.

209. Moheghi N, Afshari JT, Brook A. The Cytotoxic Effect of Zingiber Afficinale in Breast Cancer (MCF7) Cell Line. Quarterly of Horizon of Medical Sciences. 2011;17(3):28-34.

210. Safari MG, Baesi K, Hosseinkhani S. An alternative approach in regulation of expression of a transgene by endogenous miR-145 in carcinoma and normal breast cell lines. Biotechnology and applied biochemistry. 2015.

211. Pirouzpanah S, Taleban FA, Mehdipour P, Atri M. Association of folate and other one-carbon related nutrients with hypermethylation status and expression of RARB, BRCA1, and RASSF1A genes in breast cancer patients. Journal of molecular medicine (Berlin, Germany). 2015;93(8):917-34.

212. ZARGHAMI N.A. AJ. EFFECT OF ZINC, SELENIUM AND COPPER IN CELL LINE OF BREAST CANCER ON TELOMERASE GENE EXPRESSION. PHARMACEUTICAL SCIENCES. 2007;-(2):8.

213. Ghezelbash B, Ghaderi Pakdel F, Mohammad Hasan Z, Zare S, Tokmechi A, Hobbenaghi R, et al. THE EFFECTS OF LACTOBACILLUS RHAMNOSUS LMG18243 ON GROWTH OF BREAST CANCER IN INBRED BALB/C MICE. URMIA MEDICAL JOURNAL. 2011;22(3):230-8.

214. Othman F, Ideris A, Motalleb G, Bt Eshak Z, Rahmat A. Oncolytic Effect of Newcastle Disease Virus AF2240 Strain on the MCF7 Breast Cancer Cell Line2009.

215. HALAKOUEI M. YMH, SARAF Z.H., MAHDAVI M., ESKANDARI A. EVALUATION THE EFFECT OF CANDIDA ALBICANS INFECTIONS (CANDIDIASIS) ON TUMOR MASS STATUS, INTRA TUMOR CD4/CD8 RATIO OF THE MAMMARY TUMOR IN BALB/C MICE

216. KOWSAR MEDICAL JOURNAL. 2007;12(1):12.

217. Orangy e, Hojati Z, Ghaedi K, Tabatabaeean M. Comparison of the HER2/neu gene amplification assesment by differential PCR and immunohistochemistry in breast cancer patients in Isfahan. Journal of Shahrekord Uuniversity of Medical Sciences. 2012;13(6):71-82.

218. Rassi H, Gorovenko NG, Houshmand M, Podolskaya SV, Hashemi M, Majidzadeh K, et al. Application of multiplex PCR with histopathologic features for detection of familial breast cancer in formalin-fixed, paraffin-embedded histological specimens. Cytology and Genetics. 2008;42(2):120-6.

219. Tabatabaeian H, Hojati Z. Assessment of HER-2 gene overexpression in Isfahan province breast cancer patients using Real Time RT-PCR and immunohistochemistry. Gene. 2013;531(1):39-43.

220. Pazhoomand R, Keyhani E, Banan M, Najmabadi H, Khodadadi F, Iraniparast A, et al. Detection of HER2 status in breast cancer: comparison of current methods with MLPA and real-time RT-PCR. Asian Pacific journal of cancer prevention : APJCP. 2013;14(12):7621-8.

221. Kadivar M, Shayanfar N, Bahraminejad M, Sadeghipour A, Askarzadeh P. Interpretation of immunohistochemistry results of HER2/neu expression in invasive breast cancer: Evaluation of interobserver and intraobserver agreement in Iran. Journal of Clinical Oncology. 2008;26(15).

222. Rafiee-Pour HA, Behpour M, Keshavarz M. A novel label-free electrochemical miRNA biosensor using methylene blue as redox indicator: application to breast cancer biomarker miRNA-21. Biosensors \& bioelectronics. 2015;77:202-7.

223. Rasti M, Honardar Z, Nikseresht M, Owji A. Quantitative Analysis of ErbB1 and ErbB2 Genes Amplification by a High Performance Liquid Chromatography. Avicenna journal of medical biotechnology. 2014;6(4):228-37.

224. Salimi M, Mozdarani H, Majidzadeh AK. Efficacy of primed in situ labelling in determination of HER-2 gene amplification and CEN-17 status in breast cancer tissue. Asian Pacific journal of cancer prevention : APJCP. 2012;13(1):329-37.

225. Shamsipour F, Zarnani AH, Ghods R, Chamankhah M, Forouzesh F, Vafaei S, et al. Conjugation of Monoclonal Antibodies to Super Paramagnetic Iron Oxide Nanoparticles for Detection of her2/neu Antigen on Breast Cancer Cell Lines. Avicenna journal of medical biotechnology. 2009;1(1):27-31.

Page $30 / 31$ 
226. Rismanchi S, Yadegar O, Muhammadnejad S, Amanpour S, Taghizadeh-Jahed M, Muhammadnejad A. Expression of vimentin filaments in canine malignant mammary gland tumors: A simulation of clinicopathological features of human breast cancer. Biomedical reports. 2014;2(5):725-8.

227. Oskouee MA, Shahmahmoodi S, Jalilvand S, Mahmoodi M, Ziaee AA, Esmaeili HA, et al. No evidence of mammary tumor virus env gene-like sequences among Iranian women with breast cancer. Intervirology. 2014;57(6):353-6.

228. Razmkhah M, Jaberipour M, Ghaderi A. Bcl-2 and Fas expressions correlate with proliferative specificity of adipose-derived stem cells (ASCs) in breast cancer. Immunological investigations. 2011;40(3):290-8.

229. Kennecke H, Yerushalmi R, Woods R, Cheang MCU, Voduc D, Speers CH, et al. Metastatic behavior of breast cancer subtypes. Journal of clinical oncology. 2010;28(20):3271-7.

230. Amani D, Zahir M, Karimzadeh M, Feizollah Zadeh S, Dehghan M. Immunophenotyping Analysis of Tumor Infiltrating T Lymphocytes in Patients with Breast Cancer. Journal of Ardabil University of Medical Sciences. 2007;7(4):344-52.

231. Shariatpanahi S, Soleimani_Darjagh M, Salehi R. Relation between the Presence of Mouse Mammary Tumor Virus-Like Sequences in Breast Tissues and Human Breast Cancer in Iranian Patients JOURNAL OF ISFAHAN MEDICAL SCHOOL (IUMS) 2013;31(227):208-17.

232. Zamanian-Azodi M, Rezaei-Tavirani M, Rahmati-Rad S, Hasanzadeh H, Rezaei Tavirani M, Seyyedi SS. Protein-Protein Interaction Network could reveal the relationship between the breast and colon cancer. Gastroenterology and hepatology from bed to bench. 2015;8(3):215-24.

233. Rismanchi S, Muhammadnejad S, Amanpour S, Muhammadnejad A. First pathological study of canine primary breast lymphoma and the description of its clinicopathological characteristics as an animal model for human primary breast lymphoma. Biomedical reports. 2015;3(1):75-7.

234. Shafiee R, Javanbakht J, Atyabi N, Bahrami A, Kheradmand D, Safaei R, et al. Comparative value of clinical, cytological, and histopathological features in feline mammary gland tumors; an experimental model for the study of human breast cancer. Diagnostic pathology. 2013;8:136.

235. Shafiee R, Javanbakht J, Atyabi N, Kheradmand P, Kheradmand D, Bahrami A, et al. Diagnosis, classification and grading of canine mammary tumours as a model to study human breast cancer: an Clinico-Cytohistopathological study with environmental factors influencing public health and medicine. Cancer cell international. 2013;13:79.

236. Modeling of metastatic breast cancer in BALB/c mouse with mouse derived cell line and stably transduction of this cell line with lentiviral vector. Iranian Quarterly Journal of Breast Diseases. 2011;4(1):7-12.

237. Seyednoori T, Pakseresht S, Roushan Z. Risk of developing breast cancer by utilizing Gail model. Women \& health. 2012;52(4):391-402.

238. Investigation of mutation in the BRCA1 and BRCA2 genes in breast cancer patients and their relatives in Ahwaz, Iran. Clinical Biochemistry. 2005;38(9):842-

239. HOSSEINPOUR R. HNE, RANJPOOR F., SORI M., PEYVANDI H., MIRHASHEMI S.H., KHOSHKAR A., . EVALUATION OF THE RISK OF BREAST CANCER, BASED ON THE GAIL MODEL, IN WOMEN OF MORE THAN 35 YEARS OLD: AT HEALTH CENTERS OF YASOUJ DURING 2010-2011. IRANIAN JOURNAL OF SURGERY 2012;20(3):8.

240. Vahidnezhad H, Youssefian L, Jeddi-Tehrani M, Akhondi MM, Rabbani H, Shokri F, et al. Modeling breast acini in tissue culture for detection of malignant phenotype reversion to non-malignant phenotype. Iranian biomedical journal. 2009;13(4):191-8.

241. Hamta A, SHariatzadeh S, Soleimani M, Seifi F. Introduction and Bioinformatic's Evaluation of Candidate Genes in Breast Cancer Using Cytogenetic Studies of Cancer Induction. Journal of Zanjan University of Medical Sciences. 2011;19(74):63-77.

242. HAMTA A. SSMA, SOLEYMANI MALEK, SEYFI FATEMEH. CHROMOSOMAL REARRANGEMENT AND BIOINFORMATIC STUDIES OF THE INVOLVED GENES IN DMBA-INDUCED BREAST CANCER IN SD RAT STRAINS AND VERIFICATION OF THEIR SYNTENIC SEGMENTS IN HUMAN CHROMOSOMS. JOURNAL OF KERMAN UNIVERSITY OF MEDICAL SCIENCES. 2010;17(3):17.

243. Shariat S, Badiee A, Jaafari MR, Mortazavi SA. Optimization of a Method to Prepare Liposomes Containing HER2/Neu- Derived Peptide as a Vaccine Delivery System for Breast Cancer. Iranian journal of pharmaceutical research : IJPR. 2014;13(Suppl):15-25.

244. Majidzadeh-A K, Kaviani A, Esmaeili R, Farahmand L, Shojamoradi MH, Zare AA, et al. Iranian Breast Cancer Bio-Bank: the activity and challenging issues. Cell Tissue Bank. 2013;14(1):11-20.

245. He D-X, Gu F, Gao F, Hao J-j, Gong D, Gu X-T, et al. Genome-wide profiles of methylation, microRNAs, and gene expression in chemoresistant breast cancer. Scientific Reports. 2016;6:24706.

246. Wilting RH, Dannenberg J-H. Epigenetic mechanisms in tumorigenesis, tumor cell heterogeneity and drug resistance. Drug Resistance Updates. 2012;15(1):21-38.

\section{Supplementary Files}

This is a list of supplementary files associated with this preprint. Click to download.

- CHART.pdf

- PRISMAIPDchecklist.pdf 